\title{
Determination of Enantioselectivities by Means of Chiral Stationary Phase HPLC in Order to Identify Effective Proline-Derived Organocatalysts
}

\author{
Jorge Vargas-Caporali*,a and Eusebio Juaristi*,a,b \\ ${ }^{a}$ Departamento de Química, Centro de Investigación y de Estudios Avanzados del Instituto Politécnico Nacional, \\ Apartado Postal 14-740, 07360 Ciudad de México, Mexico \\ ${ }^{b}$ El Colegio Nacional, Luis González Obregón No. 23, Centro Histórico, 06020 Ciudad de México, Mexico
}

\begin{abstract}
The pyrrolidine fragment is a privileged scaffold within chiral ligands employed in coordination complexes exhibiting catalytic activity in asymmetric reactions and, more recently, as enantioselective organocatalysts per se. Likewise, the employment of $(S)$-proline as starting material constitutes the most direct form to synthesize those chiral derivatives. Afterwards, a preliminary evaluation of the catalytic performance of proline-derived compounds consists of screening many prochiral substrates in well standardized model reactions such as Michael additions and Mannich reactions, with the aim of identifying "broad spectrum" catalysts for more complex synthetic applications. Therefore, a central part of this process involves the fast and direct measurement of enantioselectivities of optically active adducts. The growing development of chiral stationary phases and thus, the wide commercial availability of chiral columns have consolidated high performance liquid chromatography (HPLC) as the preferred technique to identify the most effective catalysts.
\end{abstract}

Keywords: proline derivatives, asymmetric organocatalysis, chiral stationary phases, chiral HPLC

\section{Introduction}

In recent times, a growing demand for enantiopure, value-added chiral compounds such as pharmaceuticals, food additives and agrochemicals has been registered. ${ }^{1}$ Likewise, one of the major aims of organic synthesis is the creation of molecular diversity and complexity from simple and readily available substrates. ${ }^{2}$ Therefore, the development of stereoselective synthetic strategies focused on those classes of organic molecules has increased in an extraordinary way.

Asymmetric synthesis makes use of different analytical techniques such as X-ray diffraction, ${ }^{3}$ chiral nuclear magnetic resonance (NMR) shift reagents, ${ }^{4}$ chiral chromatography, ${ }^{5}$ among others, ${ }^{6}$ with the aim of evaluating the efficiency of a given strategy, either via chiral auxiliaries, ${ }^{7}$ asymmetric catalysis mediated by metal complexes, ${ }^{8}$ enzymatic catalysis ${ }^{9}$ and, a more recently developed methodology, organocatalysis. ${ }^{10}$

\section{Brief Overview of Chiral Stationary Phases}

In the beginnings of asymmetric synthesis, enantiomeric

*e-mail: jvargas@relaq.mx; juaristi@relaq.mx

This paper is part of the PubliSBQ Special Issue "IUPAC-2017" (http://publi.sbq.org.br/). purities of chiral compounds were usually determined by comparison of experimental optical rotations or via the preparation of diastereomeric derivatives followed by analysis of their ${ }^{1} \mathrm{H}$ NMR spectra. This situation gradually changed since Gil-Av et al. (1966) ${ }^{11}$ achieved the analytical separation of single enantiomers from racemic $\alpha$-amino acids by means of a chiral stationary phase for gas chromatography (GC). Thus, chiral chromatography currently allows a direct comparison of chromatograms obtained from enantioenriched samples with those recorded from the corresponding racemates. High performance liquid chromatography (HPLC) is the preferred technique over GC for most of the chiral analytes since it not only allows the analysis of enantiopurity, but also the easy recovery of the sample or even the enantio-enrichment of optically active compounds at the semipreparative or preparative scale. ${ }^{12} \mathrm{GC}$ is ideal for the analytical resolution of volatile substances, especially chiral hydrocarbons, which pose a special challenge due to the lack of functional groups that could reversibly interact with a chiral selector and thus lead to usual chiral recognition strategies. ${ }^{13}$

In general, the separation of enantiomeric compounds via chiral stationary phases is based on the formation of transient diastereomeric complexes (of different bonding 
energies) in a thermodynamic equilibrium, which in turn results from the different fitting onto the structures of chiral selectors, depending on the configurational complementarity with the functional groups belonging to the analyte. ${ }^{14}$ Therefore, one of the two transient diastereomeric complexes formed by each of the enantiomers comprising a racemate will be more stabilized by means of potential intermolecular interactions such as hydrogen bonding, $\pi-\pi$ complexation, dipole stacking, ionic and/or steric interactions, and others. ${ }^{14}$ In this regard, in-depth studies have allowed a sophisticated understanding of the chiral recognition mechanisms performed by enantioselective stationary phases, though forefront research continues emerging. ${ }^{15}$ Hence, it is plausible to achieve the analytical resolution of almost any existent chiral compound given the presently available chiral stationary phases.
Two main groups of chiral stationary phases (CSPs) for HPLC can be recognized: ${ }^{5}$

(i) Brush-type chiral stationary phases (or selectorbased chiral sorbents) that usually consist of relatively small chiral molecules immobilized onto an achiral support (e.g., organic polymers or silica gel particles). Chiral metal complexes,${ }^{16}$ crown ethers, ${ }^{17}$ cyclodextrins, ${ }^{18}$ cyclofructans, ${ }^{19}$ antibiotics, ${ }^{20}$ Pirkle-type receptors, ${ }^{21}$ zwitterionic quinine-based selectors, ${ }^{22}$ among others enter in this category. ${ }^{23}$

(ii) Sorbents based on optically active polymers, which can be synthetic such as the molecularly imprinted polymers ${ }^{24}$ or obtained from natural sources, e.g. polysaccharides derivatives ${ }^{25}$ or protein based CSP. ${ }^{26}$

Figure 1 depicts some salient examples of the abovementioned chiral stationary phases..$^{27-33}$ Table 1
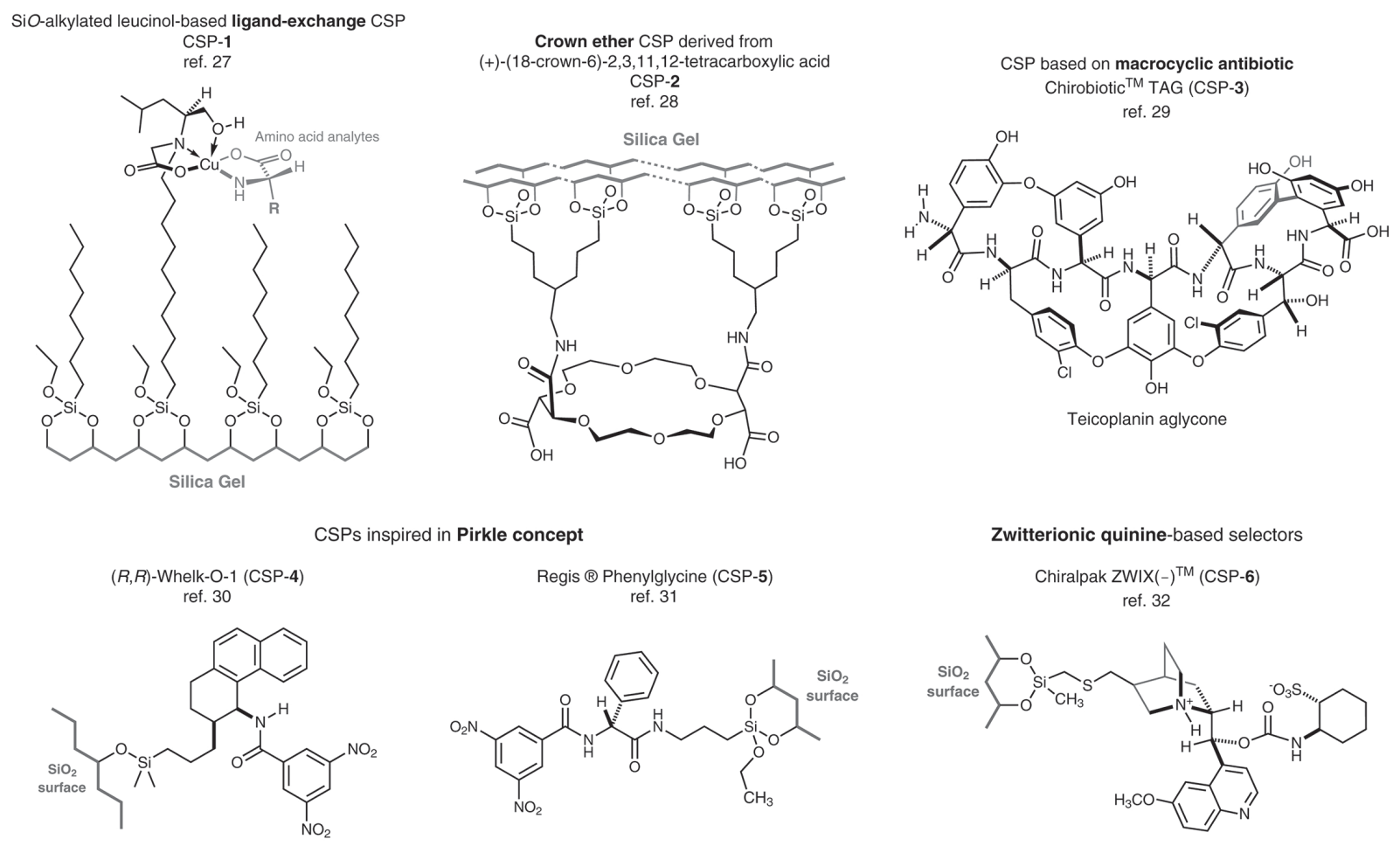

Polysaccharydes-based CSPs (ref. 33)
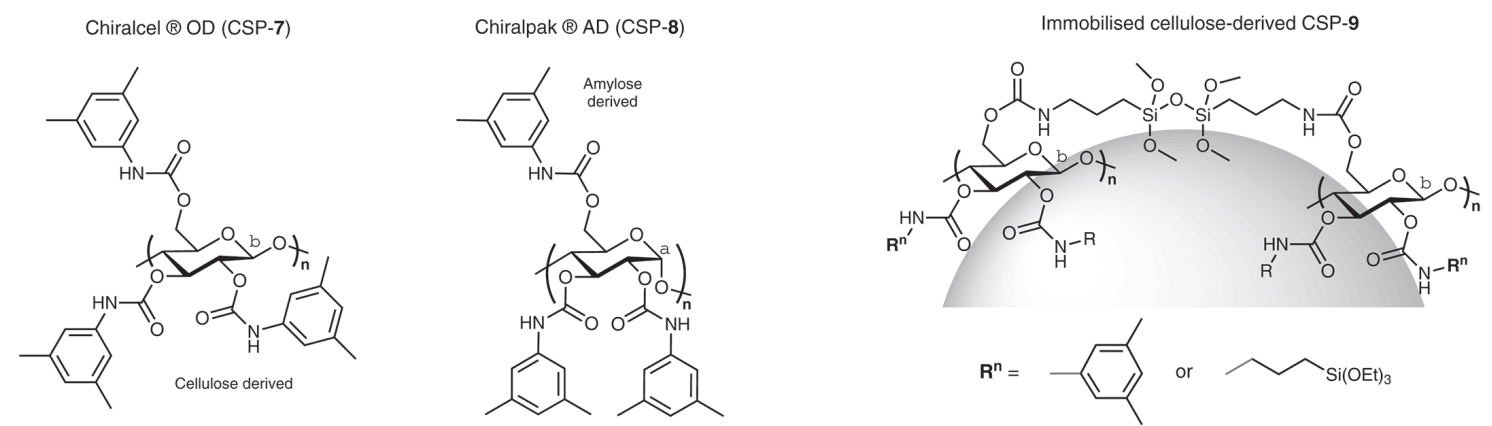

Figure 1. Some relevant examples of chiral selectors developed for their use in liquid chromatography (all structures are adapted from the corresponding references). 
Table 1. Salient developments regarding chiral selectors for HPLC (based on the summary table compiled by Lämmerhofer) ${ }^{22}$

\begin{tabular}{|c|c|c|c|c|c|}
\hline Year & Research group & Pioneering work & Reference & $\begin{array}{l}\text { Compounds resolved in the } \\
\text { chiral selector }\end{array}$ & Main features of the chiral selector \\
\hline \multicolumn{6}{|c|}{ Early developments } \\
\hline 1966 & Gil-Av et al. & $\begin{array}{l}\text { resolution by gas } \\
\text { chromatography using amino } \\
\text { acid derivatives as chiral } \\
\text { selector }\end{array}$ & 11 & natural amino acids & $\begin{array}{l}\text { first baseline analytical resolution by gas } \\
\text { chromatography }\end{array}$ \\
\hline 1971 & Rogozhin and Davankov & $\begin{array}{l}\text { first CSP (based on proline } \\
\text { derivative and divinylbenzene } \\
\text { polymer support) for LC } \\
\text { enantiomer separation by } \\
\text { enantioselective ligand } \\
\text { exchange }\end{array}$ & 34 & amino acids & first baseline resolution by $\mathrm{LC}$ \\
\hline 1973 & Hesse and Hagel & $\begin{array}{l}\text { first polysaccharide-based } \\
\text { enantiomer separation on } \\
\text { microcrystalline cellulose } \\
\text { triacetate }\end{array}$ & 35 & Tröger's base & $\begin{array}{l}\text { this achievement led to the observation that the } \\
\text { secondary structure of the natural polymer was } \\
\text { crucial for the sorption of the analyte }\end{array}$ \\
\hline 1973 & Stewart and Doherty & $\begin{array}{l}\text { CSP based on proteins: } \\
\text { enantiomer separation on } \\
\text { bovine serum albumin bound } \\
\text { to sepharose }\end{array}$ & 36 & tryptophan & $\begin{array}{l}\text { complete resolution of DL-tryptophan was } \\
\text { accomplished when chromatographed on } \\
\text { bovine-serum albumin-succinoyl-aminoethyl- } \\
\text { sepharose }\end{array}$ \\
\hline 1974 & Blaschke & $\begin{array}{l}\text { resolution using optically } \\
\text { active polyacrylamides }\end{array}$ & 37 & $\begin{array}{c}\text { mandelic acid and ephedrine } \\
\text { derivatives }\end{array}$ & $\begin{array}{l}\text { the recognition ability of these polymers } \\
\text { depends on the employed synthetic methods } \\
\text { since the chiral recognition sites within the } \\
\text { CSPs must be formed during the polymerization } \\
\text { process. } \\
\text { the polymers exhibited a remarkably higher } \\
\text { chiral recognition when prepared by the radical } \\
\text { polymerization of optically active monomers in } \\
\text { comparison to those prepared by the reaction of } \\
\text { poly(acryloyl chloride) with the corresponding } \\
\text { chiral amines. It has been found that the tacticity } \\
\text { of polymethacrylamides influenced their chiral } \\
\text { recognition abilities }{ }^{5,24}\end{array}$ \\
\hline
\end{tabular}

\begin{tabular}{|c|c|c|c|c|c|}
\hline \multicolumn{6}{|c|}{ chiral crown ethers } \\
\hline 1975 & 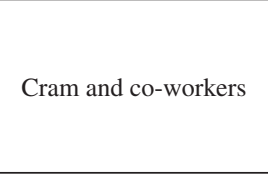 & $\begin{array}{c}\text { chiral crown ethers } \\
\text { [bis(dinaphthyl)-22-crown-6] } \\
\text { coated and covalently } \\
\text { immobilized on silica gel for } \\
\text { amino-acid esters }\end{array}$ & 38 & $\begin{array}{l}\text { natural or unnatural } \alpha \text {-amino } \\
\text { acids (or their esters) }\end{array}$ & $\begin{array}{c}\text { chiral selectors capable of resolving compounds } \\
\text { bearing a primary amino functionality }\end{array}$ \\
\hline 1976 & Gil-Av and co-workers & $\begin{array}{c}\text { first donor-acceptor type CSP } \\
\text { (later known as Pirkle concept) } \\
\text { based on oxime derivatives of } \\
\text { lactic acid and analogues of it }\end{array}$ & 39 & helicenes & $\begin{array}{l}\text { coated and bonded chiral charge-transfer } \\
\text { complexing agents as stationary phases }\end{array}$ \\
\hline 1979 & Pirkle et al. & $\begin{array}{l}\text { first Pirkle CSP, based on } \\
\text { 2,2,2-trifluoro-1-(9-anthryl) } \\
\text { ethanol-bonded selector }\end{array}$ & 31,41 & $\begin{array}{c}N \text {-acyl-1-arylaminoalkanes; } \\
\text { piperidines and polyhydro- } \\
\text { isoquinolines; chiral } \\
\text { secondary arylalkyl-carbinols; } \\
\text { derivatives of BINOL; } \\
\text { hydantoins and succinimides }\end{array}$ & $\begin{array}{l}\text { small molecules with groups acting as donors or } \\
\text { receptors of } \pi \text { electrons leading to the formation } \\
\text { of } \pi-\pi \text { charge transfer (face to face or face to } \\
\text { edge) diastereomeric complexes with a specific } \\
\text { enantiomer. Greater uniformity in distribution } \\
\text { of chiral selectors upon the inert matrix, } \\
\text { amplified enantio-recognition via effective steric } \\
\text { barriers from structurally rigid fragments being } \\
\text { part of these selectors, tailor-made molecular } \\
\text { design for specific analytes, mobile or reverse } \\
\text { phases allowed, mechanical stability, chemical } \\
\text { inertness, capacity to separate high sample } \\
\text { loading and an exceptionally good accessibility } \\
\text { to chiral selectors with different features in both } \\
\text { enantiomeric forms }\end{array}$ \\
\hline \multicolumn{6}{|c|}{ Landmark papers that have led to modern (silica-based) CSPs and commercial columns } \\
\hline 1984 & Hermansson & $\begin{array}{l}\alpha_{1} \text {-acid glycoprotein-bonded } \\
\text { CSP (Chiralpak AGP) }\end{array}$ & 42 & $\begin{array}{c}\text { twelve racemic drug } \\
\text { substances from different } \\
\text { pharmacological groups (e.g. } \\
\text { tropicamide, mepivacaine, } \\
\text { mepensolate bromide) }\end{array}$ & $\begin{array}{l}\alpha_{1} \text {-AGP stationary phase proved to be highly } \\
\text { stable since no tendency for degradation of the } \\
\text { solid phase or denaturation of protein could be } \\
\text { observed after daily use during prolonged period }\end{array}$ \\
\hline
\end{tabular}


Table 1. Salient developments regarding chiral selectors for HPLC (based on the summary table compiled by Lämmerhofer) ${ }^{22}$ (cont.)

\begin{tabular}{|c|c|c|c|c|c|}
\hline Year & Research group & Pioneering work & Reference & $\begin{array}{l}\text { Compounds resolved in the } \\
\text { chiral selector }\end{array}$ & Main features of the chiral selector \\
\hline \multicolumn{6}{|c|}{ Landmark papers that have led to modern (silica-based) CSPs and commercial columns } \\
\hline 1984 & Okamoto et al. & $\begin{array}{l}\text { polysaccharide CSPs obtained } \\
\text { by coating of cellulose } \\
\text { and amylose esters and } \\
\text { carbamates onto the surface of } \\
\text { macroporous silica particles }\end{array}$ & 43 & $\begin{array}{l}\text { Pirkle's alcohol, Tröger's } \\
\text { base; acrylates and } \\
\text { methacrylates, anticholinergic } \\
\text { drugs, miscellaneous } \\
\text { compounds }\end{array}$ & $\begin{array}{l}\text { the grooves-shaped asymmetric structure } \\
\text { characteristic of polysaccharide polymers allows } \\
\text { the adsorption of enantiomers via inclusion } \\
\text { mechanism. Cellulose triacetate and tribenzoate } \\
\text { coated onto aminopropyl-silanised macroporous } \\
\text { silica gel exhibited enhanced mass transfer and } \\
\text { substantial mechanical stability }\end{array}$ \\
\hline 1984 & Allenmark et al. & $\begin{array}{c}\text { immobilized bovine serum } \\
\text { albumin as a chiral stationary } \\
\text { phase (Resolvosil, Chiralpak } \\
\text { human serum albumin (HSA)) }\end{array}$ & 44 & $\begin{array}{l}N \text {-acylated } \alpha \text {-amino acids, } \\
\text { benzoin }\end{array}$ & $\begin{array}{l}\text { immobilized protein as CSP using aqueous } \\
\text { buffer systems as eluents }\end{array}$ \\
\hline 1986 & Armstrong et al. & $\begin{array}{l}\text { B-cyclodextrin-bonded CSP } \\
\text { (Cyclobond I and others) }\end{array}$ & 45 & $\begin{array}{l}\text { diverse enantiomeric drugs: } \\
\beta \text {-adrenergic blockers, } \\
\text { antihistamine, sedative } \\
\text { anticonvulsants (barbitals), } \\
\text { central nervous system } \\
\text { stimulant, cinchona alkaloids, } \\
\text { antiestrogens, among others }\end{array}$ & $\begin{array}{l}\text { separation of stereoisomers of diverse drugs } \\
\text { by the formation of } \beta \text {-cyclodextrin inclusion } \\
\text { complexes }\end{array}$ \\
\hline 1992 & Pirkle et al. & $\begin{array}{l}\text { Donor-acceptor CSP with } \\
\pi \text {-acidic and } \pi \text {-basic aromatic } \\
\text { moieties (Whelk O1) }\end{array}$ & 30,46 & $\begin{array}{c}\text { profens; } N \text {-Boc or } \\
N \text {-Cbz } \alpha \text {-amino acids; } \\
\alpha \text {-aryloxy propionic acids, } \\
\text { primary and secondary } \\
\text { alcohols, diols, } \alpha \text {-hydroxy } \\
\text { ketones, } \alpha \text {-substituted } \\
\text { cyclohexanones, oxiranes, } \\
\text { aziridines; phthalides, } \\
\text { lactams, } \gamma \text {-lactones; } \\
\text { oxazolidinones }\end{array}$ & $\begin{array}{l}\text { the discriminating ability of this class of selector } \\
\text { has been attributed to a "pre-organized" cleft } \\
\text { which provides an active site in which but } \\
\text { one enantiomer of a profen could undergo } \\
\text { simultaneous hydrogen bonding, } \pi-\pi \text { face-to- } \\
\text { face stacking, and } \pi \text { - } \pi \text { face-to-edge interaction } \\
\text { while in a relatively low energy conformation }\end{array}$ \\
\hline \multirow[t]{2}{*}{1994} & \multirow[t]{2}{*}{ Armstrong et al. } & $\begin{array}{l}\text { macrocyclic-antibiotic-based } \\
\text { CSPs (Chirobiotic V, T, } \\
\text { TAG, R). }\end{array}$ & \multirow[t]{2}{*}{29,47} & \multirow{2}{*}{$\begin{array}{c}\text { warfarin, proglumide, } \\
\text { bendroflumethiazide; amino } \\
\text { acids (free, } N \text {-acylated or } \\
O \text {-methylated); Chirobiotic }{ }^{\mathrm{TM}} \\
\text { TAG: common } \alpha \text {-amino acids } \\
\text { and other carboxylic acids; } \\
\text { Chirobiotic }{ }^{\mathrm{TM}} \mathrm{T} \text { : atenolol } \\
\text { and pindolol ( } \beta \text {-blockers); } \\
\text { uncommon analogues of } \\
\text { phenylalanine; } \beta \text {-amino acids }\end{array}$} & $\begin{array}{c}\text { macrocycles are functionally diversified, } \\
\text { possessing many stereogenic centers, so } \\
\text { the chiral recognition might be carried } \\
\text { through different mechanisms including } \pi-\pi \\
\text { complexation, hydrogen bonding, hydrophobic } \\
\text { pocket, dipole stacking, steric interactions, or } \\
\text { their combinations }{ }^{20}\end{array}$ \\
\hline & & $\begin{array}{l}\text { V: vancomycin; T: teicoplanin; } \\
\text { TAG: teicoplanin aglycone; } \\
\text { R: ristocetin A }\end{array}$ & & & $\begin{array}{l}\text { CSPs based on macrocyclic antibiotics could be } \\
\text { used in both normal and reversed mobile phases } \\
\text { (multimodal selectors) }\end{array}$ \\
\hline 1996 & $\begin{array}{l}\text { Lämmerhofer and } \\
\text { Lindner }\end{array}$ & $\begin{array}{c}\text { quinine-carbamate-based CSPs } \\
\text { (Chiralpak QN-AX) }\end{array}$ & 48 & $\begin{array}{l}N \text {-protected Phe derivatives; } \\
\text { other chiral carboxylic acids }\end{array}$ & $\begin{array}{l}\text { these chiral selectors immobilized onto porous } \\
\text { silica have preferentially operated with buffered } \\
\text { aqueous mobile phases to resolve enantiomers of } \\
\text { acidic analytes, involving ion pair mechanisms } \\
\text { as the dominating binding interaction } \\
\end{array}$ \\
\hline 1996 & Francotte & $\begin{array}{l}\text { immobilized polysaccharide } \\
\text { CSPs (Chiralpak IA, IB, IC, } \\
\text { etc.) }\end{array}$ & 49 & $\begin{array}{l}\text { initially, optically active } \\
\text { compounds usually employed } \\
\text { as standards to test CSP were } \\
\text { resolved: benzoin, Tröger's } \\
\text { base, trans-stilbene oxide, } \\
\text { benzodiazepines, etc. }\end{array}$ & $\begin{array}{c}\text { photochemically cross-linked polysaccharide } \\
\text { derivatives in which the } \mathrm{OH} \text { groups have been } \\
\text { esterified as OR' groups or converted into a } \\
\text { carbamate. The use of } \mathrm{CH}_{2} \mathrm{Cl}_{2} \text { or THF is allowed } \\
\text { since covalent binding avoids the sweeping } \\
\text { observed for polysaccharides only physically } \\
\text { adsorbed } \\
\end{array}$ \\
\hline 1998 & $\begin{array}{l}\text { Machida et al. } \\
\text { Hyun et al. }\end{array}$ & $\begin{array}{l}\text { covalently bonded } 18 \text {-crown- } \\
\text { 6-tetracarboxylic-acid-based } \\
\text { CSP (ChiroSil) }\end{array}$ & 50 & $\begin{array}{c}\text { amines, } \alpha \text {-amino acids, } \alpha \\
\text { and } \beta \text {-amino acids, } \alpha \text {-amino } \\
\text { amides, aryl } \alpha \text {-amino } \\
\text { ketones, primary amines and } \\
\text { amino alcohols } \\
\text { chiral drugs: } \\
\text { benzodiazepinones, } \\
\text { mexiletine analogues, amino } \\
\text { esters of acyclovir, } \beta \text {-blockers } \\
\beta^{2} \text { - and } \beta^{3} \text {-homo-amino acids }\end{array}$ & $\begin{array}{l}\text { tetracarboxylic-acid-derived crown ether chiral } \\
\text { selectors have proved being successful for the } \\
\text { resolution of various primary amino compounds } \\
\text { with the use of aqueous mobile phases } \\
\text { containing organic and acidic modifiers }\end{array}$ \\
\hline
\end{tabular}


Table 1. Salient developments regarding chiral selectors for HPLC (based on the summary table compiled by Lämmerhofer) ${ }^{22}$ (cont.)

\begin{tabular}{|c|c|c|c|c|c|}
\hline Year & Research group & Pioneering work & Reference & $\begin{array}{l}\text { Compounds resolved in the } \\
\text { chiral selector }\end{array}$ & Main features of the chiral selector \\
\hline 2008 & Lindner and co-workers & $\begin{array}{l}\text { zwitterionic quinine- } \\
\text { carbamate-based CSPs } \\
\text { (Chiralpak ZWIX) }\end{array}$ & 51 & $\begin{array}{l}\beta \text {-blockers, } N \text {-protected } \\
\text { natural } \alpha \text {-amino acids, } \\
\text { free natural and unnatural } \\
\alpha \text {-amino acids with } \\
\text { pharmaceutical activity, } \\
\quad \beta \text {-amino acids } \\
\end{array}$ & $\begin{array}{l}\text { ion exchanger type chiral stationary phases } \\
\text { based on zwitterionic selectors. These selectors } \\
\text { interact with ionizable analytes via ionic } \\
\text { interactions, but } \pi-\pi \text { interactions and hydrogen } \\
\text { bonding contribute to the stabilization of the } \\
\text { complex }\end{array}$ \\
\hline 2009 & Armstrong and co-workers & $\begin{array}{l}\text { cyclofructan-based CSPs } \\
\text { (Larich series) }\end{array}$ & 52 & $\begin{array}{c}\text { trans-1-amino-2- } \\
\text { indanol, Tröger's base, } \\
\text { orphenadrine citrate salt, } \\
N \text {-(3,5-dinitrobenzoyl)- } \\
\text { DL-leucine, thalidomide, } \\
\text { among others } \\
\alpha \text {-aryl ketones }{ }^{19}\end{array}$ & $\begin{array}{l}\text { aliphatic functionalized cyclofructans possess } \\
\text { unique enantiomeric selectivities to separate } \\
\text { a broad range of racemic compounds, it is } \\
\text { possible to modulate the affinity of cyclofructans } \\
\text { by partially derivatizing the hydroxyl groups } \\
\text { therefore disrupting internal hydrogen bonding }\end{array}$ \\
\hline
\end{tabular}

CSP: chiral stationary phase; LC: liquid chromatography; DL: D (dextrorotation) and L (laevorotation); BINOL: 1,1'-bi-2-naphthol.

summarizes progress on the development of chiral liquid chromatography. ${ }^{22,34-52}$

From stationary phases based on naturally occurring chiral compounds such as $\alpha$-amino acid derivatives to the design of synthetic chiral receptors, chiral chromatography constitutes a medullar part in the assessment of new asymmetric synthetic strategies through the fast determination of enantiomeric excesses (ee) in routine reaction tests encompassing multiple samples. Currently, the most widely employed chiral columns are those presenting polysaccharide-derived stationary phases due to their broad-spectrum applicability for optically active analytes of almost any nature.

\section{Synopsis of the Development of Organo- catalysts and their Applications}

Organocatalysis, conventionally defined as the use of small organic molecules as catalysts to promote asymmetric organic transformations, is now considered a stablished strategy for asymmetric synthesis. ${ }^{53}$ Though the term organocatalysis was introduced by Ostwald in 1900, ${ }^{54}$ it remained relatively forgotten until the 1970's when Hajos and Parrish (Hoffmann-La Roche) ${ }_{5}^{55}$ and Eder et al. (Schering) ${ }^{55}$ independently reported the intramolecular aldol reaction catalyzed by $(S)$-proline, whose product was obtained in 99\% yield and 93\% enantiomeric excess. This asymmetric approach experienced a rebirth since 2000, when List et al. ${ }^{56}$ published their seminal work describing the employment of proline as organocatalyst in the enantioselective intermolecular aldol reaction between acetone and different aldehydes.

Proline is an abundant $\alpha$-amino acid available in both enantiomeric forms. Its functional amino and carboxylic groups situated at a convenient distance confer the proline a great versatility as organocatalyst since on one side of the molecular structure, the carboxylic acid fragment allows the formation of hydrogen bonds with one heteroatom from a non-enolizable electrophile and on the other side, the secondary amine functionality participates in the formation of a nucleophilic enamine with an enolizable aldehyde or ketone..$^{57}$ The modification of the carboxylic acid functionality can modulate the capability of forming hydrogen bonds, in turn improving the solubility of resulting proline-derived catalysts. With respect to the second point, bifunctional pyrrolidine catalysts have been also obtained from trans-hydroxyproline, whose hydroxy group enables the support of the organocatalyst onto silica gel (heterogeneous catalysis) or ionic tags (ionic liquid catalytic systems), thus facilitating their recovery. Figure 2 depicts grosso modo the development of ligands with an efficient organocatalytic activity, from simple and affordable chiral compounds such as amino acids, up to molecules with greater complexity and versatility. ${ }^{58-71}$

Given the great diversity of reactions in which it is possible to employ $(R)$ - or $(S)$-proline and its derivatives as organocatalysts, it is worthy to mention that relatively few methods of activation were initially identified..$^{10,71,72}$ For example, the stereoinduction observed in reactions listed in Figure 3 is ruled by a simplified rationalization of the mechanistic principle of catalysis via enamine.

On the other hand, the applications of chiral organocatalysts have not been limited to the development of asymmetric methodologies, but have also fruitfully extended to the asymmetric synthesis of various chiral natural and synthetic bioactive compounds. ${ }^{73}$

For instance, Hong et al. ${ }^{74}$ developed the enantioselective total synthesis via cascade threecomponent organocatalysis of (+)-conicol $[(+)-\mathbf{2 6}$, Scheme 1], an interesting chiral compound isolated from the ascidian Aplidium conicum, that has exhibited antiproliferative activity against human acute lymphoblastic 


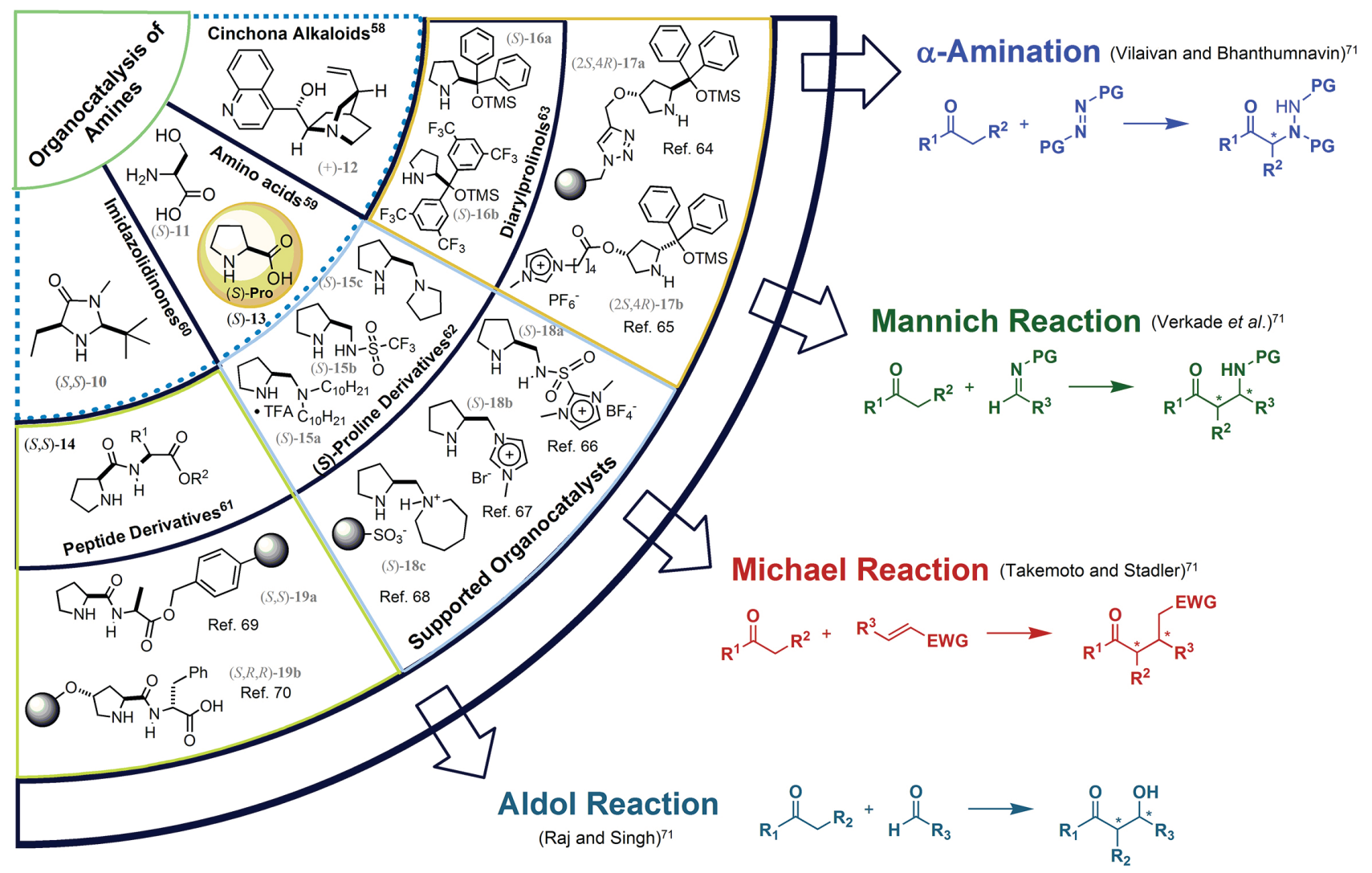

Figure 2. Early development of organocatalysts.

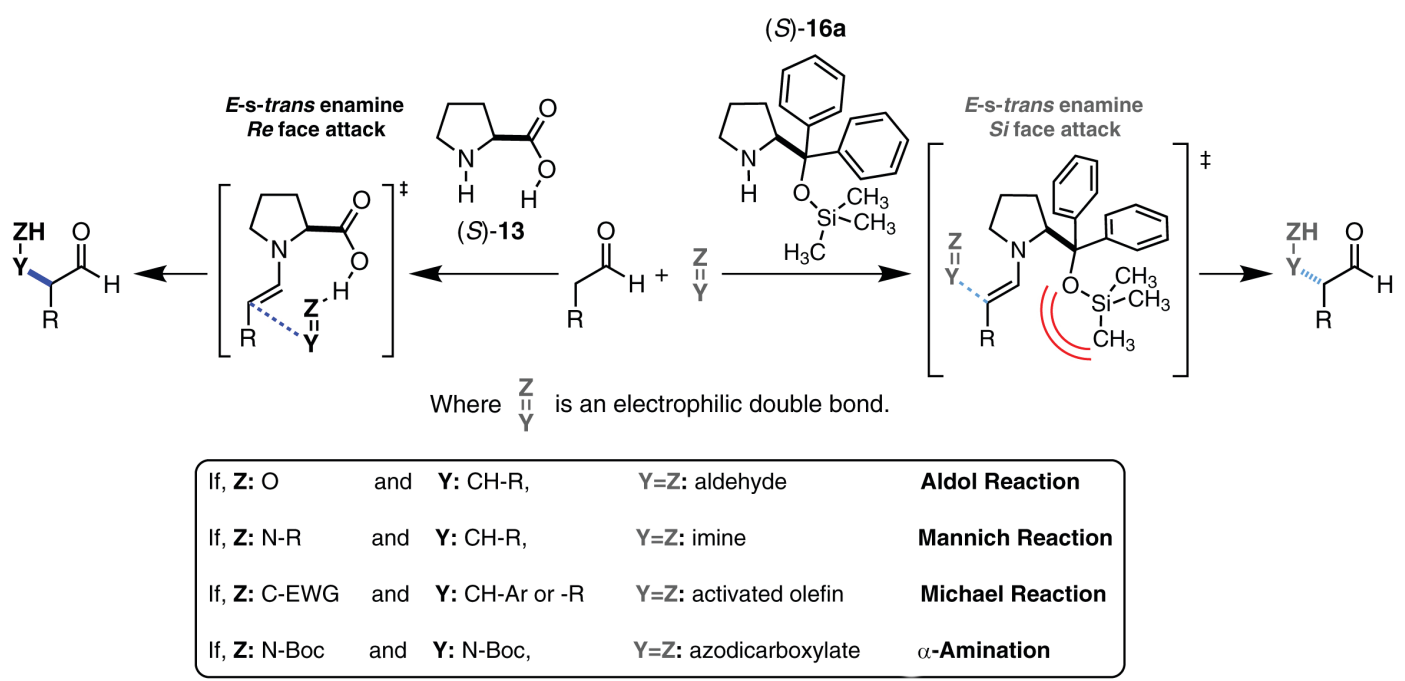

Figure 3. General asymmetric $\alpha$-functionalizations of aldehydes by means of enamine addition to electrophilic double bonds.

leukemia CEM-WT cells as well as antibacterial activity against the Gram-positive bacteria Micrococcus luteus. Hong et $a .^{74}$ envisioned that precursor $\gamma$-nitro aldehyde (23) could be asymmetrically assembled by means of the tandem oxa-Michael-Michael reaction between (E)-2-(2-nitrovinyl)-benzene-1,4-diol (20), 3-methylbut2-enal (21) employing the Jørgensen-Hayashi catalyst $(S)-\mathbf{1 6 a}$. The subsequent reaction to obtain $\mathbf{2 4}$ from precursor 23 could be achieved in one-pot in $66 \%$ overall yield. An alternative sequence involving diverse reduction and oxidation reactions allowed the preparation of the final product (+)-conicol, (+)-26. The development of this synthetic route also permitted the unambiguous assignment of its absolute configuration by means of X-ray diffraction.

Thus, one of the main aims in our research group is the development of new ligands with potential organocatalytic 


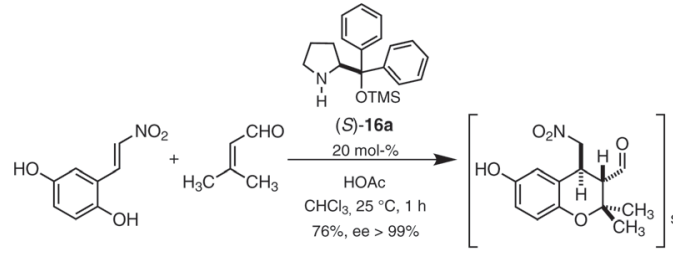

22

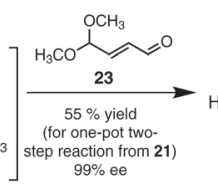

$99 \%$ ee

trans-20

21

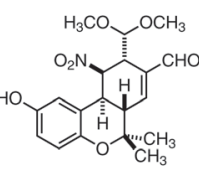

24

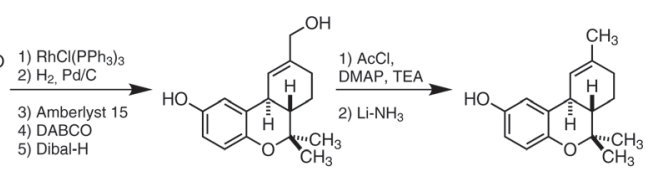

25

$(+)$-conicol $[(+)-26]$

Scheme 1. Synthetic route for (+)-conicol developed by Hong et $a l .{ }^{74}$ (adapted).

activity, in which the evaluation of enantioselectivities via chiral HPLC plays a central role.

\section{Diazabicycloheptanes as Organocatalysts}

$(1 S, 4 S)$-2,5-Diazabicyclo[2.2.1]heptane, $(1 S, 4 S)$-29, was deemed a promising chiral scaffold for diverse applications in asymmetric catalysis. This compound can be easily prepared from trans-4-(S)-hydroxyproline (Scheme 2), and several derivatives were tested as chiral ligands coordinating metal reagents or as organocatalysts themselves in different asymmetric reactions, inducing enantioselectivities with varying levels of success. In particular, diethylzinc addition to carbonyls of aldehydes was the most successful. ${ }^{75}$

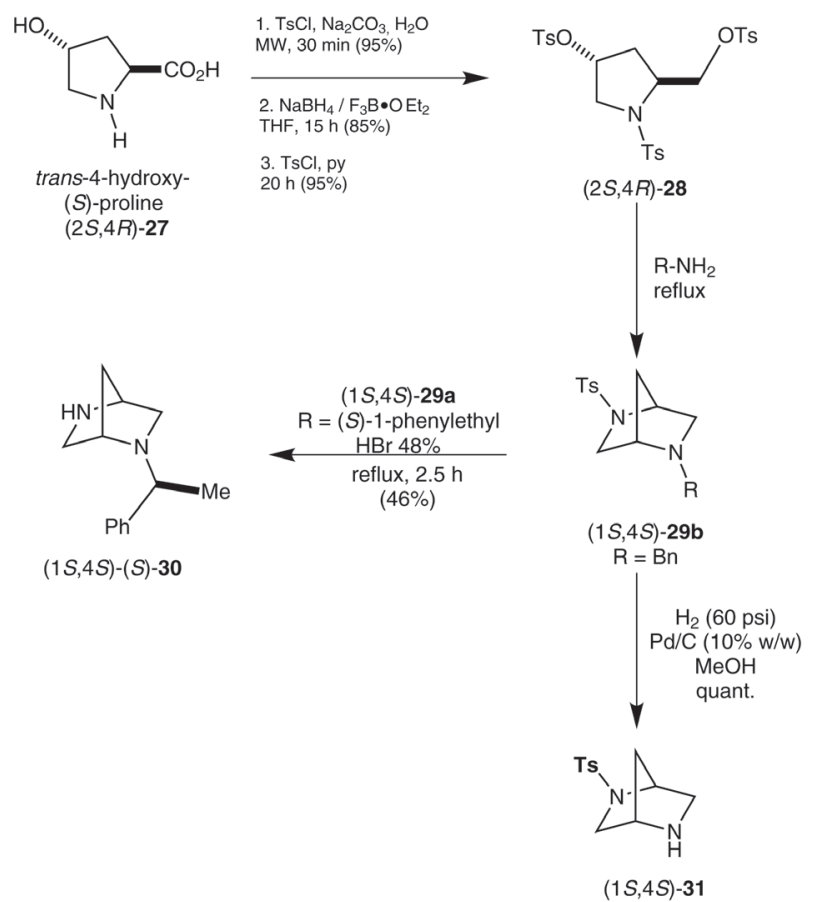

Scheme 2. Synthesis of chiral diazabicycloheptanes ligands.

Furthermore, in one of the first examples of organocatalyzed asymmetric Biginelli reaction, the hydrobromide of diazabicycloheptane $(1 S, 4 S)-(R)-\mathbf{3 0}$ afforded moderate results (Scheme 3$).{ }^{76}$ Outstandingly good resolutions were achieved for the series of chiral cyclic ureas (35) by means of using Chirobiotic ${ }^{\mathrm{TM}} \mathrm{T}$ column. Figure 4 shows a typical example of chromatograms for a product of the tested Biginelli reaction.

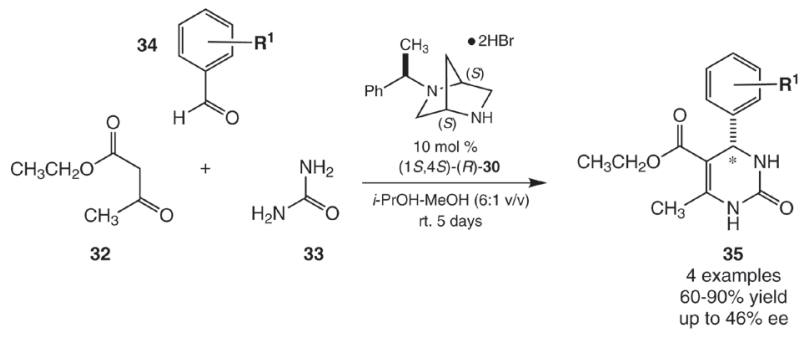

Scheme 3. Asymmetric Biginelli reaction catalyzed by diazabicycloheptane $(1 S, 4 S)-(R)-\mathbf{3 0}$.

More recently, it was found that diastereomeric salts of diazabicycloheptane $(1 S, 4 S)$-31 combined with $(R)$-mandelic acid $[(R)-38]$ successfully organocatalyzed the Michael addition reaction under solvent-free conditions. ${ }^{77}$ A general overview of performance of $(1 S, 4 S)$-31 in the aforementioned reaction is depicted in Scheme 4. These results were interesting since it has been known that the structural nature of an acidic proton source had no influence on stereoselectivity given that acid additives tend to carry out general acid catalysis type. ${ }^{72}$

\section{Organocatalysis via Proline Dipeptide Derivatives Assisted by Mechanochemistry}

Mechanochemical synthesis involves mechanical grinding of the corresponding reagents under solvent free conditions or in the presence of molar equivalents of a suitable solvent (e.g. water), either generated during the reaction or added (minimal solvent). The reaction usually proceeds with no heating other than that produced from the conversion of the mechanical energy of milling into heat, being the dispersion and an incremented surface area the determining factors in reactions subjected to the mechanical action. ${ }^{78} \mathrm{~A}$ wide range of applications of mechanochemistry have been found, not only in areas typically related to mechanical grinding such as in the preparation of oxides, ${ }^{79}$ metal complexes, ${ }^{80}$ energy-related or environmental 

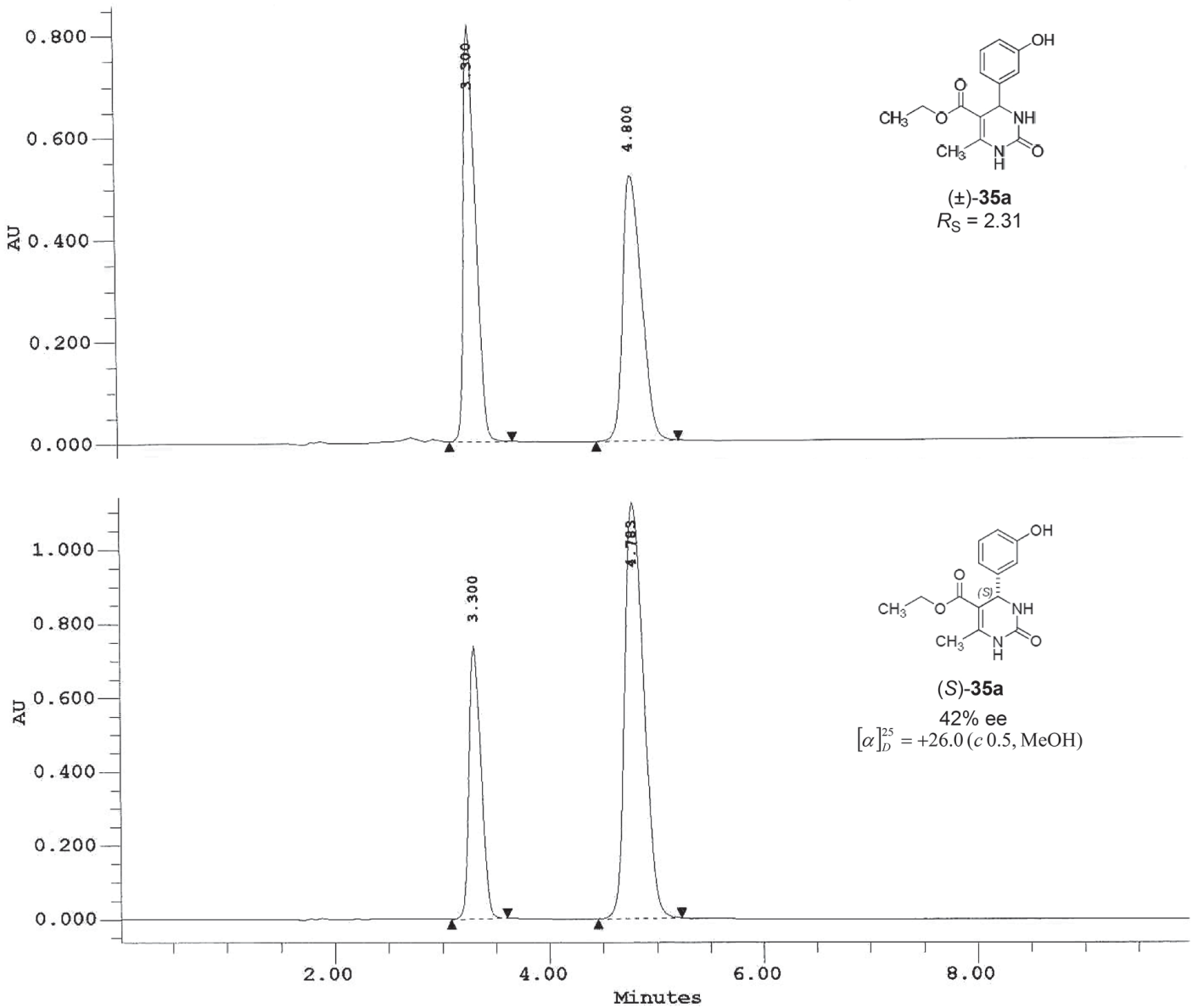

Figure 4. Comparison of chromatograms (racemic $v s$. enantioenriched sample) corresponding to 3,4-dihydro-pyrimidin-2(1H)-one, 35a. Chromatographic conditions: Chirobiotic T $(0.46 \times 25 \mathrm{~cm}, 10 \mu \mathrm{m})$, mobile phase acetonitrile:water $(70: 30 \mathrm{v} / \mathrm{v}), \lambda=230 \mathrm{~nm}$ and U $=1 \mathrm{~mL} \mathrm{~min}^{-1}$; retention time $\left(\mathrm{t}_{\mathrm{R}}\right)=3.30 \mathrm{~min}$ (enantiomer $R$, minor); $\mathrm{t}_{\mathrm{R}}=4.78$ min (enantiomer $S$, major).

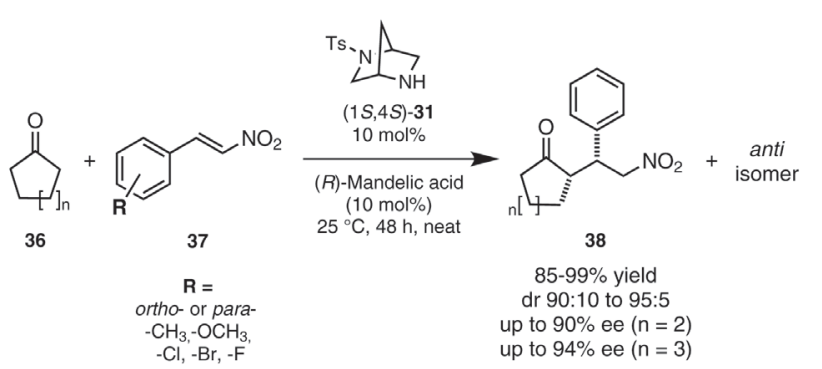

Scheme 4. Solvent-free Michael addition reaction of cyclic ketones to different nitroolefins catalyzed by $(1 S, 4 S)-\mathbf{3 1}$.

heterogeneous catalysts ${ }^{81}$ and metal-organic frameworks or hosts for molecular inclusions, ${ }^{82}$ but also in non-traditional fields such as molecular co-crystal formation ${ }^{83}$ and production of pharmaceutical materials. ${ }^{84}$ In recent years, mechanochemistry has also constituted a developing field of interest in organic synthesis, ${ }^{85,86}$ thus ball-milling has been successfully employed in the synthesis of peptides and aromatic amides, ${ }^{87}$ in the preparation of substituted hydantoins from dipeptides ${ }^{88}$ in carbon-heteroatom bond forming reactions, in the synthesis of heterocycles,${ }^{89}$ in the synthesis of Ugi 4-CR and Passerini 3-CR adducts, ${ }^{90}$ in cross-coupling reactions as well as in other metal-catalyzed organic processes. ${ }^{91}$

Likewise, asymmetric organocatalysis can also take advantage of mechanochemical tools to carry out solvent free (or minimal solvent versions) of existing reactions which proceed via enamine formation among other activation mechanisms. ${ }^{92}$ In this regard, it should be noted the pioneering work implemented by Bolm and co-workers, ${ }^{93}$ and Nájera and co-workers ${ }^{94}$ in aldol and Michael reactions under ball-milling activation.

Our research group evaluated the organocatalytic activity of the methyl ester of $(S)$-proline-( $(S)$-phenylalanine dipeptide $(S, S)$-39 in the asymmetric aldol reactions between cyclohexanone or acetone together with various aromatic aldehydes under ball-milling, solvent-free conditions. ${ }^{95}$ Using a milling frequency of $2760 \mathrm{rpm}(46 \mathrm{~Hz})$ at $-20{ }^{\circ} \mathrm{C}$, dipeptide $(S)$-39 stereoselectively catalyzed the formation of aldol products in yields as high as $94 \%$, with up to 91:9 anti:syn d.r. (diastereomeric ratio) and up to $95 \%$ ee. 
Furthermore, $(S)$-proline-containing thiodipeptides could also be employed for the mechanochemical asymmetric aldol reaction, which in some cases proved to be better organocatalysts relative to their amide analogues $[(S, S)$-39 vs. $(S, S)-43] .{ }^{96}$ Equally, the methyl ester of $(S)$-proline$(S)$-tryptophan $(S, S)$-44 combined with benzoic acid as additive and a small amount of water, afforded higher diastereo- and enantioselectivities (up to 98:2 anti:syn d.r. and up to
$98 \%$ ee). ${ }^{97}$ More recently, $O$-methyl esters of proline-derived $\alpha, \beta$-dipeptides, e.g. $(S)-\mathbf{4 5}$, have been evaluated, ${ }^{98}$ as well as amides supported on MBHA (4-methylbenzhydrylamine) resin, (S)-46. ${ }^{99}$ Table 2 summarizes the selected results regarding the obtained enantioselectivities induced by diverse organocatalysts in aldol reactions. Table 2 also includes the available details of the chromatographic separations of the resulting stereoisomeric products.

Table 2. Organocatalyzed direct aldol reaction between cyclohexanone and aryl-aldehydes aryl-substituted with electron-withdrawing groups (respecting to carbonyl electrophilicity)

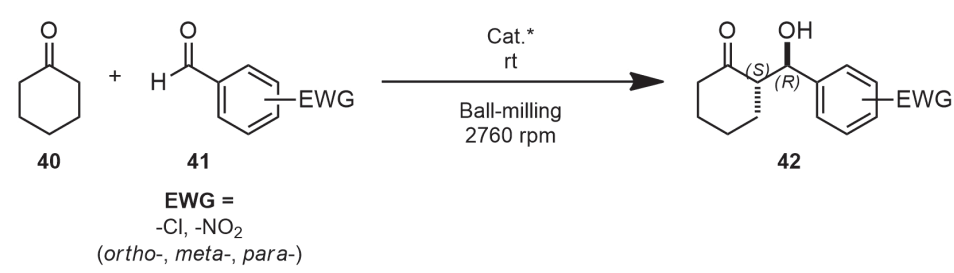

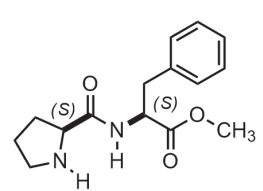

(S,S)-39

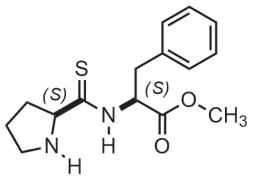

(S,S)-43

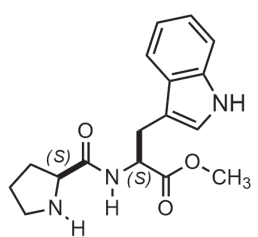

$(S, S)-44$

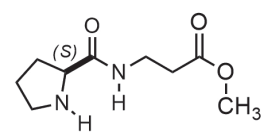

(S)-45

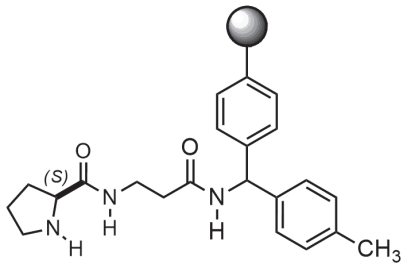

(S)-46

\begin{tabular}{|c|c|c|c|c|c|c|c|c|c|}
\hline entry & Product & Catalyst & $\begin{array}{c}\text { Optimized reaction } \\
\text { conditions }\end{array}$ & Yield / \% & d.r. $(\text { anti:syn })^{\mathrm{a}}$ & $\begin{array}{c}\text { e.r. }^{\mathrm{b}} \\
(\mathrm{ee} / \%)\end{array}$ & $\begin{array}{l}\text { Chromatographic } \\
\text { conditions }\end{array}$ & $\begin{array}{l}\text { Resolution } \\
\text { factor }\left(\mathrm{R}_{\mathrm{S}}\right)\end{array}$ & $\mathrm{t}_{\mathrm{R}} / \min$ \\
\hline 1 & & $\begin{array}{l}(S, S)-39 \\
(7 \mathrm{~mol} \%)\end{array}$ & $\begin{array}{l}\mathbf{4 0 : 4 1}(1.1: 1) \\
-20^{\circ} \mathrm{C}, 4 \mathrm{~h}\end{array}$ & 92 & $90: 10$ & $\begin{array}{l}97.5: 2.5 \\
\quad(95)\end{array}$ & & & \\
\hline 2 & & $\begin{array}{c}(S, S)-\mathbf{4 3} \\
(7 \mathrm{~mol} \%)\end{array}$ & $\begin{array}{l}\mathbf{4 0 : 4 1}(1.1: 1) \\
-20^{\circ} \mathrm{C}, 4 \mathrm{~h}\end{array}$ & 89 & $98: 2$ & $\begin{array}{l}95.5: 4.5 \\
(91)\end{array}$ & & & $\frac{a n t i}{23}$ \\
\hline 3 & & $\begin{array}{c}(S, S)-44 \\
(3 \mathrm{~mol} \%)\end{array}$ & $\begin{array}{c}\text { 40:41 (1.1:1) } \\
1.1 \text { equiv. } \mathrm{H}_{2} \mathrm{O} \\
\mathrm{PhCO}_{2} \mathrm{H} \\
5 \mathrm{~mol}^{\circ} \\
-20^{\circ} \mathrm{C}, 6 \mathrm{~h}\end{array}$ & 88 & $92: 8$ & $\begin{array}{c}99: 1 \\
(>98)\end{array}$ & 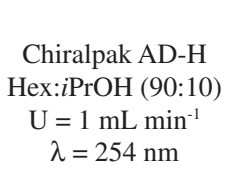 & $\begin{array}{l}6.99(\text { anti) } \\
3.52(\text { syn })\end{array}$ & $\begin{array}{l}\text { (minor) } \\
30.57\left(2 S, 1^{\prime} R\right) \\
\text { (major) } \\
\text { syn }\end{array}$ \\
\hline 4 & & $\begin{array}{c}(S)-\mathbf{4 5} \\
(10 \mathrm{~mol} \%)\end{array}$ & $\begin{array}{c}\text { 40:41 }(2: 1) \\
3.0 \text { equiv. } \mathrm{H}_{2} \mathrm{O} \\
\mathrm{PhCO}_{2} \mathrm{H} \\
20 \mathrm{~mol} \% \\
\mathrm{rt}, 0.5 \mathrm{~h} \\
\end{array}$ & 94 & $90: 10$ & $\begin{array}{l}91: 9 \\
(82)\end{array}$ & & & $\begin{array}{l}18.35 \\
20.78\end{array}$ \\
\hline 5 & $42 a$ & $\begin{array}{c}(S)-\mathbf{4 6} \\
(10 \mathrm{~mol} \%)\end{array}$ & $\begin{array}{c}\text { excess of } 40 \\
\mathrm{H}_{2} \mathrm{O} \text { (solvent) } \\
\mathrm{PhCO}_{2} \mathrm{H} \\
20 \mathrm{~mol} \% \\
\mathrm{rt}, 6 \mathrm{~h} \\
\end{array}$ & 97 & $94: 6$ & $\begin{array}{l}89: 11 \\
(78)\end{array}$ & 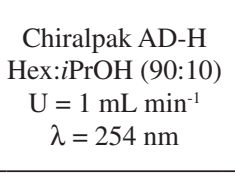 & $\begin{array}{l}6.99 \text { (anti) } \\
3.52(\text { syn) }\end{array}$ & 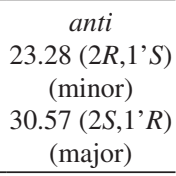 \\
\hline 6 & & $\begin{array}{l}(S, S)-39 \\
(7 \mathrm{~mol} \%)\end{array}$ & $\begin{array}{l}\mathbf{4 0 : 4 1}(1.1: 1) \\
-20^{\circ} \mathrm{C}, 4 \mathrm{~h}\end{array}$ & 94 & $88: 12$ & $\begin{array}{l}87.5: 2.5 \\
(85)\end{array}$ & & & \\
\hline 7 & & $\begin{array}{l}(S, S)-43 \\
(7 \mathrm{~mol} \%)\end{array}$ & $\begin{array}{l}\mathbf{4 0 : 4 1}(1.1: 1) \\
-20^{\circ} \mathrm{C}, 6 \mathrm{~h}\end{array}$ & 86 & $92: 8$ & $\begin{array}{l}98: 2 \\
(96)\end{array}$ & & & $\begin{array}{c}\text { anti } \\
23.28\left(2 S, 1^{\prime} R\right)\end{array}$ \\
\hline 8 & $42 b$ & $\begin{array}{l}(S, S)-44 \\
(3 \mathrm{~mol} \%)\end{array}$ & $\begin{array}{c}\text { 40:41 }(1.1: 1) \\
1.1 \text { equiv. } \mathrm{H}_{2} \mathrm{O} \\
\mathrm{PhCO}_{2} \mathrm{H} \\
5 \mathrm{~mol} \% \\
-20{ }^{\circ} \mathrm{C}, 6 \mathrm{~h}\end{array}$ & 90 & $93: 7$ & $\begin{array}{l}94: 6 \\
(88)\end{array}$ & 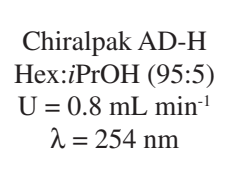 & $\begin{array}{l}7.30 \text { (anti) } \\
1.62 \text { (syn) }\end{array}$ & $\begin{array}{l}\text { (major) } \\
30.57\left(2 R, 1^{\prime} S\right) \\
\text { (minor) } \\
\text { syn }\end{array}$ \\
\hline 9 & & $\begin{array}{c}(S)-\mathbf{4 5} \\
(10 \mathrm{~mol} \%)\end{array}$ & $\begin{array}{c}\text { 40:41 }(2: 1) \\
3.0 \text { equiv. } \mathrm{H}_{2} \mathrm{O} \\
\mathrm{PhCO}_{2} \mathrm{H} \\
20 \mathrm{~mol} \% \\
\mathrm{rt}, 0.5 \mathrm{~h}\end{array}$ & 74 & $89: 11$ & $\begin{array}{l}89: 11 \\
(78)\end{array}$ & & & $\begin{array}{l}18.35 \\
20.78\end{array}$ \\
\hline
\end{tabular}


Table 2. Organocatalyzed direct aldol reaction between cyclohexanone and aryl-aldehydes aryl-substituted with electron-withdrawing groups (respecting to carbonyl electrophilicity) (cont.)

\begin{tabular}{|c|c|c|c|c|c|c|c|c|c|}
\hline entry & Product & Catalyst & $\begin{array}{c}\text { Optimized reaction } \\
\text { conditions }\end{array}$ & Yield / \% & d.r. $(\text { anti:syn })^{\mathrm{a}}$ & $\begin{array}{c}\text { e.r. }^{\mathrm{b}} \\
(\mathrm{ee} / \%)\end{array}$ & $\begin{array}{c}\text { Chromatographic } \\
\text { conditions }\end{array}$ & $\begin{array}{l}\text { Resolution } \\
\text { factor }\left(\mathrm{R}_{\mathrm{S}}\right)\end{array}$ & $\mathrm{t}_{\mathrm{R}} / \min$ \\
\hline 10 & & $\begin{array}{l}(S, S)-\mathbf{3 9} \\
(7 \mathrm{~mol} \%)\end{array}$ & $\begin{array}{l}\text { 40:41 (1.1:1) } \\
-20^{\circ} \mathrm{C}, 4 \mathrm{~h}\end{array}$ & 88 & $89: 11$ & $\begin{array}{l}95: 5 \\
(90)\end{array}$ & & & \\
\hline 11 & & $\begin{array}{l}(S, S)-\mathbf{4 3} \\
(7 \mathrm{~mol} \%)\end{array}$ & $\begin{array}{c}\text { 40:41 (1.1:1) } \\
-20^{\circ} \mathrm{C}, 6 \mathrm{~h}\end{array}$ & 80 & $>98: 2$ & $\begin{array}{l}96.5: 3.5 \\
(93)\end{array}$ & $\begin{array}{c}\text { Chiralpak AD-H } \\
\text { Hex:iPrOH }(90: 10)\end{array}$ & & $\begin{array}{c}\text { anti } \\
19.3\left(2 S, 1^{\prime} R\right)\end{array}$ \\
\hline 12 & $42 \mathrm{c}$ & $\begin{array}{l}(S, S)-\mathbf{4 4} \\
(3 \mathrm{~mol} \%)\end{array}$ & $\begin{array}{c}\text { 40:41 }(1.1: 1) \\
1.1 \text { equiv. } \mathrm{H}_{2} \mathrm{O} \\
\mathrm{PhCO}_{2} \mathrm{H} \\
5 \mathrm{~mol}^{\circ} \\
-20^{\circ} \mathrm{C}, 6 \mathrm{~h} \\
\end{array}$ & 86 & $98: 2$ & $\begin{array}{l}97: 3 \\
(94)\end{array}$ & $\begin{array}{c}\mathrm{U}=1 \mathrm{~mL} \mathrm{~min}-1 \\
\lambda=254 \mathrm{~nm}\end{array}$ & 1.91 (anti) & $\begin{array}{c}\text { (major) } \\
20.6(2 R, 1 ' S) \\
\text { (minor) }\end{array}$ \\
\hline 13 & $42 \mathrm{c}$ & $\begin{array}{c}(S)-\mathbf{4 5} \\
(10 \mathrm{~mol} \%)\end{array}$ & $\begin{array}{c}\text { 40:41 }(2: 1) \\
3.0 \text { equiv. } \mathrm{H}_{2} \mathrm{O} \\
\mathrm{PhCO}_{2} \mathrm{H} \\
20 \mathrm{~mol}^{\circ} \\
\mathrm{rt}, 0.5 \mathrm{~h} \\
\end{array}$ & 52 & $91: 9$ & $\begin{array}{l}93: 7 \\
(86)\end{array}$ & $\begin{array}{c}\text { Chiralpak AD-H } \\
\text { Hex:iPrOH (90:10) } \\
\begin{array}{c}\mathrm{U}=1 \mathrm{~mL} \mathrm{~min} \mathrm{~m}^{-1} \\
\lambda=254 \mathrm{~nm}\end{array}\end{array}$ & 1.91 (anti) & $\begin{array}{c}a n t i \\
19.3\left(2 S, 1^{\prime} R\right) \\
\text { (major) } \\
20.6\left(2 R, 1^{\prime} S\right) \\
\text { (minor) } \\
\end{array}$ \\
\hline 14 & & $\begin{array}{l}(S, S)-\mathbf{3 9} \\
(7 \mathrm{~mol} \%)\end{array}$ & $\begin{array}{l}\text { 40:41 (1.1:1) } \\
-20^{\circ} \mathrm{C}, 4 \mathrm{~h}\end{array}$ & 80 & $91: 9$ & $\begin{array}{l}95: 5 \\
(90)\end{array}$ & & & \\
\hline 15 & & $\begin{array}{l}(S, S)-\mathbf{4 3} \\
(7 \mathrm{~mol} \%)\end{array}$ & $\begin{array}{l}\text { 40:41 (1.1:1) } \\
-20^{\circ} \mathrm{C}, 6 \mathrm{~h}\end{array}$ & 78 & $98: 2$ & $\begin{array}{l}95: 5 \\
(90)\end{array}$ & & & \\
\hline 16 & $42 d$ & $\begin{array}{l}(S, S)-\mathbf{4 4} \\
(3 \mathrm{~mol} \%)\end{array}$ & $\begin{array}{c}\text { 40:41 }(1.1: 1) \\
1.1 \text { equiv. } \mathrm{H}_{2} \mathrm{O} \\
\mathrm{PhCO}_{2} \mathrm{H} \\
5 \mathrm{~mol}^{\circ} \\
-20{ }^{\circ} \mathrm{C}, 6 \mathrm{~h}\end{array}$ & 77 & $94: 6$ & $\begin{array}{l}95: 5 \\
(90)\end{array}$ & 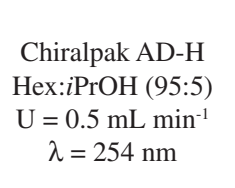 & 2.41 (anti) & $\begin{array}{c}\text { anti } \\
30.15\left(2 S, 1^{\prime} R\right) \\
\text { (major) } \\
34.44\left(2 R, 1^{\prime} S\right) \\
\text { (minor) }\end{array}$ \\
\hline 17 & & $\begin{array}{c}(S)-\mathbf{4 5} \\
(10 \mathrm{~mol} \%)\end{array}$ & $\begin{array}{c}\text { 40:41 }(2: 1) \\
3.0 \text { equiv. } \mathrm{H}_{2} \mathrm{O} \\
\mathrm{PhCO}_{2} \mathrm{H} \\
20 \mathrm{~mol} \% \\
\mathrm{rt}, 2 \mathrm{~h}\end{array}$ & 87 & $88: 12$ & $\begin{array}{l}98: 2 \\
(96)\end{array}$ & & & \\
\hline
\end{tabular}

aetermined by ${ }^{1} \mathrm{H}$ NMR spectroscopy of the crude product; betermined by chiral column HPLC of the predominant anti product. d.r.: diastereomeric ratio; e.r.: enantiomeric ratio; U: volumetric flow rate of the mobile phase.

Figure 5 collects representative chromatograms of enantioenriched diastereomeric mixtures generated with chiral dipeptides as organocatalysts. It is worthy to note that a slight difference in the substitution pattern may affect the elution order of the aldol products. For example, $p$-nitro substituted (2S,1'R)-42a (Table 2, entries 1-5) is last eluted under the chromatographic conditions employed with a Chiralpak AD-H chiral column while on the contrary, orthoand $m e t a$-nitro substituted $\left[\left(2 S, 1^{\prime} R\right)-\mathbf{4 2} \mathbf{b}\right.$ and $\left(2 S, 1^{\prime} R\right)-\mathbf{4 2 c}$, respectively] elute first.
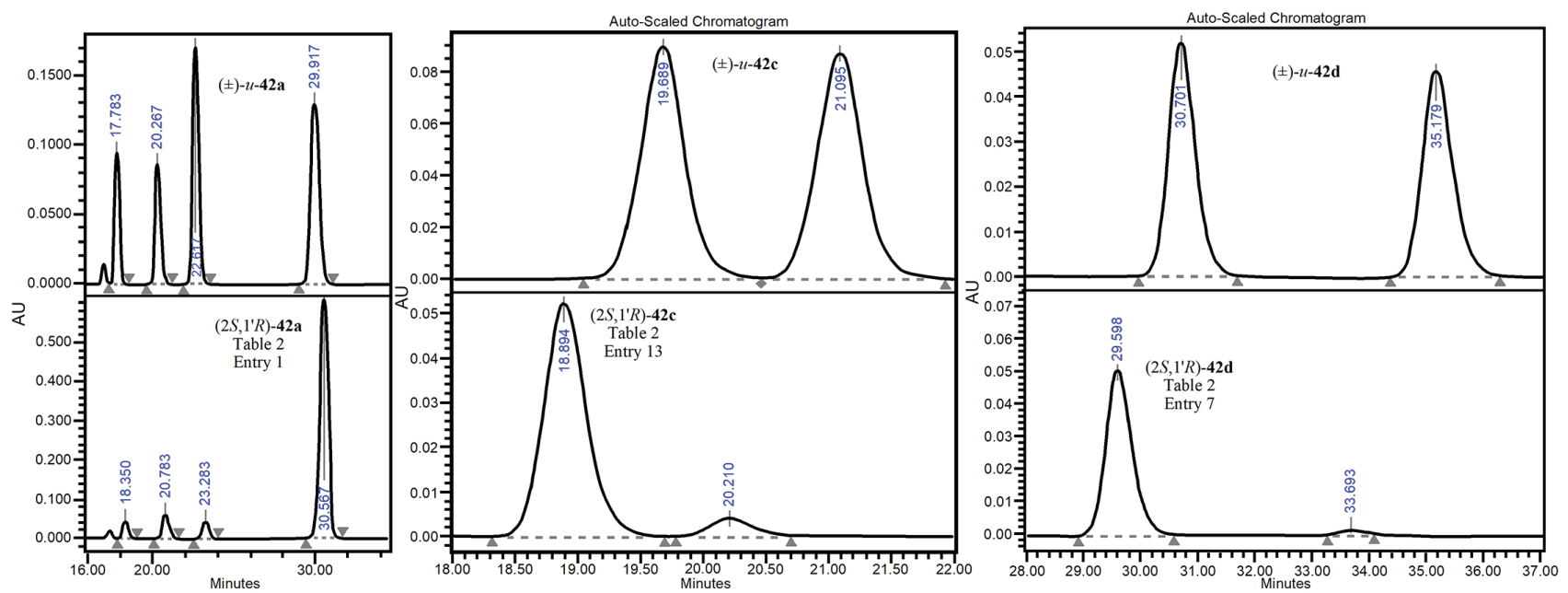

Figure 5. Comparison of chromatograms (racemic $v s$. enantioenriched samples) corresponding to aldol products (2S,1'R)-42a,c,d (left to right). 
Taking $u$-42c as example of analyte, Table 3 collects diverse chromatographic conditions employed for analysis of aldol reactions catalyzed by selected organocatalysts as recently described in the literature. Best chromatographic conditions for the analytical resolution of $( \pm)$-42c were reported by Pedotti and Patti, ${ }^{105}$ who employed a Lux Cellulose-2 column (chiral selector: cellulose tris-3-chloro4-methylphenylcarbamate, $250 \times 4.6 \mathrm{~mm}, 5 \mu \mathrm{m}$ particle size), achieving resolution factors as high as 4.53 with hexane/i-propanol (9:1) as eluent.
When evaluating new ligands as organocatalysts, unambiguous assignment of the absolute configuration of products obtained from organocatalytic reactions is crucial to make an appropriate analysis of chromatograms corresponding to racemic and enantioenriched samples. For example, Gandhi and Singh $^{106}$ developed an enantioselective synthetic route to prepare the bicyclic azetidine $(R, S, S)$-55e from aldol product $(S, R)-\mathbf{4 2 e}$, that had been obtained in a reaction catalyzed by diamino-sulfonamide $(S, R, R)$-52 (Scheme 5). Gandhi and Singh ${ }^{106}$ assigned the configuration

Table 3. Direct aldol reaction between cyclohexanone $\mathbf{4 0}$ and $o$-nitro benzaldehyde 41c promoted by small $(S)$-proline-derived organocatalysts (selected examples from literature published during 2014-2016)
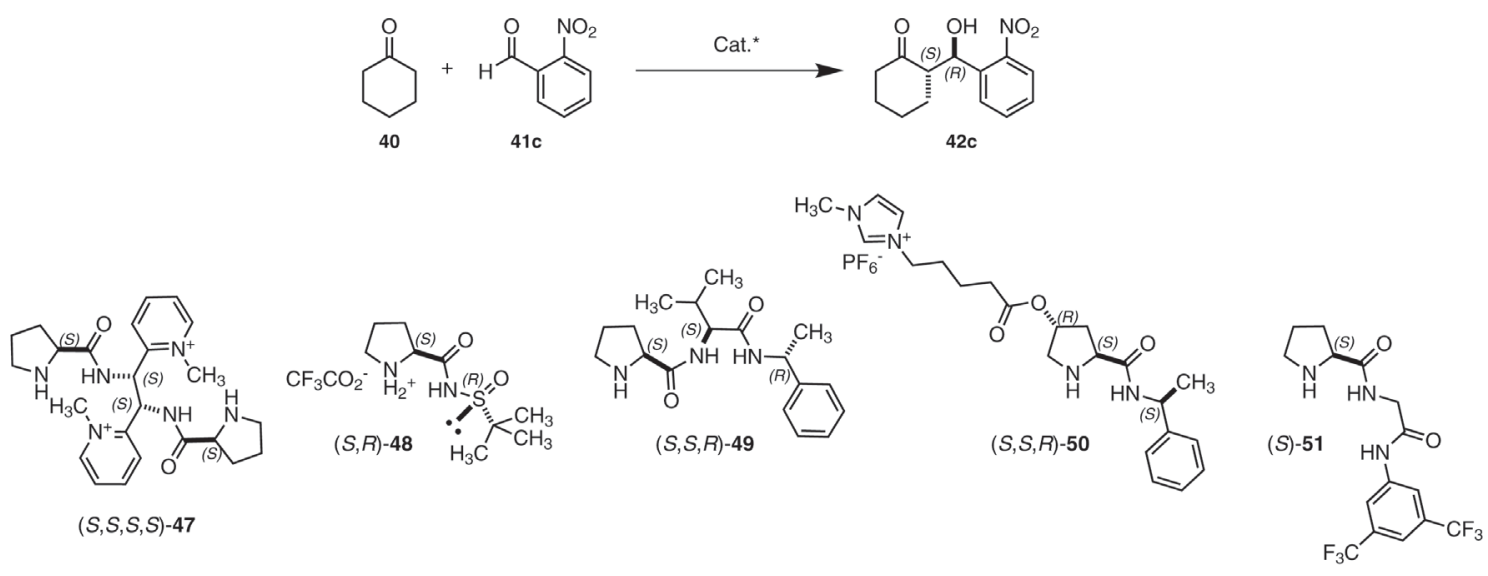

\begin{tabular}{|c|c|c|c|c|c|c|c|c|c|}
\hline entry & Catalyst & Reference & $\begin{array}{l}\text { Optimized reaction } \\
\text { conditions }\end{array}$ & Yield / \% & d.r. $(\text { anti:syn })^{\mathrm{a}}$ & ee $/ \%$ & $\begin{array}{c}\text { Chromatographic } \\
\text { conditions }\end{array}$ & $\begin{array}{c}\text { Resolution } \\
\text { factor }\left(\mathrm{R}_{\mathrm{S}}\right)^{\mathrm{a}} \\
(\text { anti })\end{array}$ & $\mathrm{t}_{\mathrm{R}} / \min (a n t i)$ \\
\hline 1 & $\begin{array}{c}(S, S, S, S)-\mathbf{4 7} \\
(5 \mathrm{~mol} \%)\end{array}$ & 100 & $\begin{array}{c}\text { 40:41c }(4: 1) \\
\mathrm{rt}, 48 \mathrm{~h}\end{array}$ & 53 & $97: 3$ & 99 & $\begin{array}{c}\text { Chiralpak OJ-H } \\
\text { Hex:iPrOH }(70: 30) \\
\begin{array}{c}\mathrm{U}=0.8 \mathrm{~mL} \mathrm{~min} \\
-1\end{array} \\
\lambda=254 \mathrm{~nm}\end{array}$ & 1.69 & $\begin{array}{l}7.4\left(2 S, 1^{\prime} R\right) \text { (major) } \\
8.0\left(2 R, 1^{\prime} S\right) \text { (minor) }\end{array}$ \\
\hline 2 & $\begin{array}{l}(S, R)-48 \\
(5 \mathrm{~mol} \%)\end{array}$ & 101 & $\begin{array}{l}\text { 40:41c }(5: 1) \\
\text { solvent-free } \\
0{ }^{\circ} \mathrm{C}, 5 \text { days }\end{array}$ & 95 & $>99: 1$ & 96 & 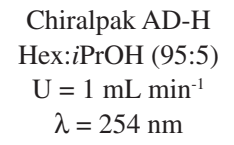 & 1.50 & $\begin{array}{l}31.54\left(2 S, 1^{\prime} R\right) \text { (major) } \\
33.26\left(2 R, 1^{\prime} S\right) \text { (minor) }\end{array}$ \\
\hline 3 & $\begin{array}{c}(S, S, R)-49 \\
(1 \mathrm{~mol} \%)\end{array}$ & 102 & $\begin{array}{l}\text { 40:brine }(1: 1) \\
\mathrm{rt}, 24 \mathrm{~h}\end{array}$ & 89 & 99:1 & 68 & 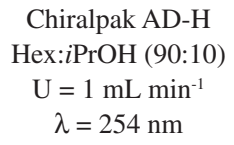 & 1.59 & $\begin{array}{l}19.25\left(2 S, 1^{\prime} R\right) \text { (major) } \\
20.76\left(2 R, 1^{\prime} S\right) \text { (minor) }\end{array}$ \\
\hline 4 & $\begin{array}{l}(S, S, R)-\mathbf{5 0} \\
(2 \mathrm{~mol} \%)\end{array}$ & 103 & $\begin{array}{c}\text { 40:41c }(3: 1) \\
\text { AcOH }(2 \mathrm{~mol} \%) \\
\text { neat } \\
-15^{\circ} \mathrm{C}, 17 \mathrm{~h}\end{array}$ & 87 & $96: 4$ & 97 & 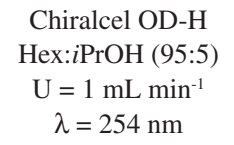 & 2.88 & $\begin{array}{l}16.14\left(2 S, 1^{\prime} R\right) \text { (major) } \\
18.47\left(2 R, 1^{\prime} S\right) \text { (minor) }\end{array}$ \\
\hline 5 & $\begin{array}{c}(S)-\mathbf{5 1} \\
(20 \mathrm{~mol} \%)\end{array}$ & 104 & $\begin{array}{c}\text { 40:41c }(10: 1) \\
p-\mathrm{NO}_{2}-\mathrm{C}_{6} \mathrm{H}_{5}-\mathrm{CO}_{2} \mathrm{H} \\
(20 \text { mol\% } \%) \\
\text { brine } \\
\text { rt, } 48 \mathrm{~h}\end{array}$ & 95 & $92: 8$ & 99 & $\begin{array}{c}\text { Chiralpak AD-H } \\
\text { Hex:iPrOH }(95: 5) \\
\begin{array}{c}\mathrm{U}=0.8 \mathrm{~mL} \mathrm{~min} \mathrm{~min}^{-1} \\
\lambda=254 \mathrm{~nm}\end{array}\end{array}$ & 1.98 & $\begin{array}{l}53.21\left(2 S, 1^{\prime} R\right) \text { (major) } \\
56.45\left(2 R, 1^{\prime} S\right) \text { (minor) }\end{array}$ \\
\hline
\end{tabular}

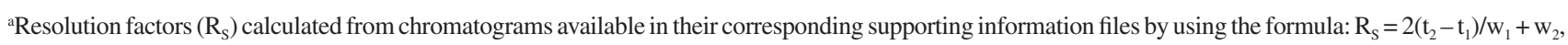
wherein, $t_{1}$ and $t_{2}$ are the retention times of the enantiomers and $w_{1}$ and $w_{2}$ are the peak widths at their baselines. d.r.: diastereomeric ratio. 


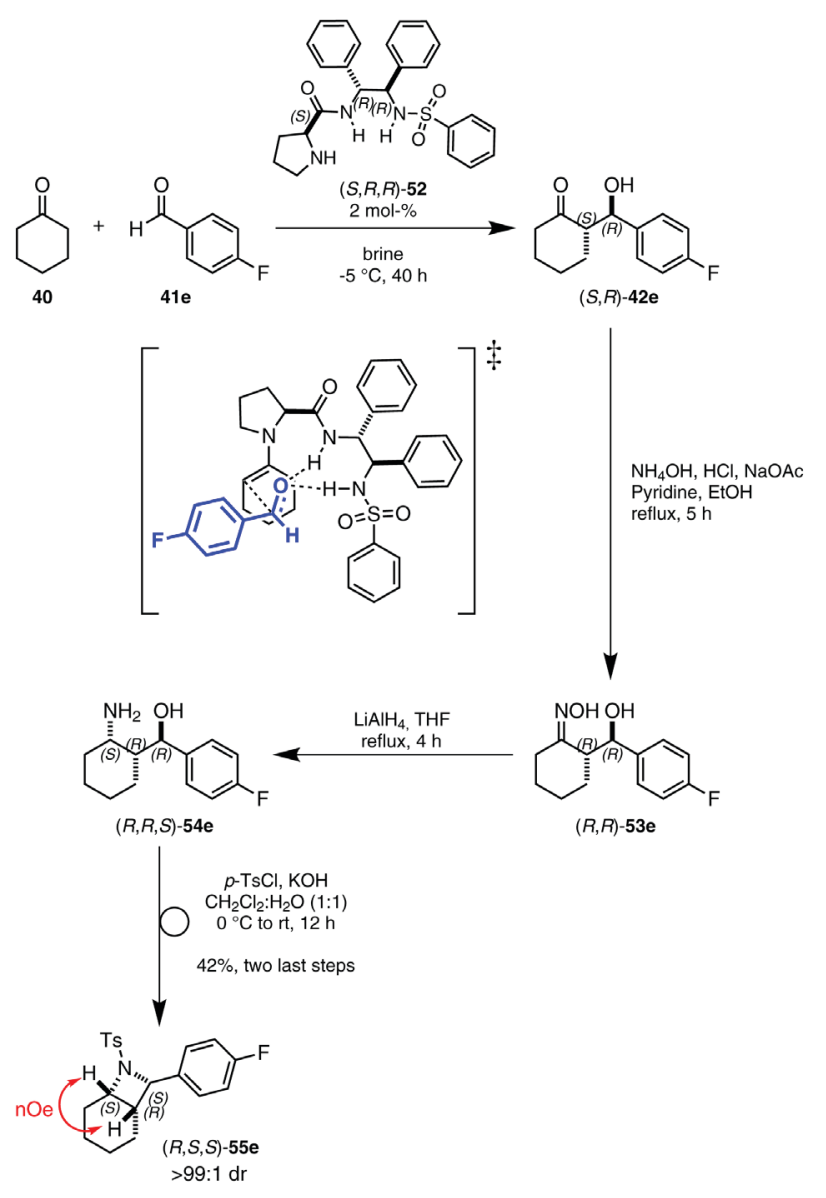

Scheme 5. Assignment of absolute configuration by NMR nOe experiment from a derivative of original aldol product.

of the new chiral centers by means of nuclear Overhauser effect (nOe) experiments; in particular, they observed an enhancement in the peak intensity of $\mathrm{H}^{2}$ by irradiating $\mathrm{H}^{1}$, and vice versa.

In the case of organocatalyst $(S, S)-\mathbf{4 4}$, chromatographic examination of the experimental stereochemical results (see Table 2, conditions described in entry 12) led to propose a reasonable transition state to explain the observed stereocontrol (Figure 6). Thus, the creation of a hydrophobic pocket enhances non-covalent $\pi$ - $\pi$ interactions between aromatic rings present both in the catalyst and in the aldehyde, so that the interaction between these fragments leads to a more rigid transition state, which is translated into a higher stereoselectivity. ${ }^{97}$

It is worth mentioning that high-speed ball milling has been recognized as an environment-friendly mechanochemical technique given that it enhances atom economy by diminishing or eliminating solvent usage when carrying out organocatalytic reactions. ${ }^{107}$ At this point, it is appropriate to mention that recent advances on separation techniques such as supercritical fluid extraction, ${ }^{108}$ solid phase extraction, ${ }^{109}$ among other practices ${ }^{110}$ might permit

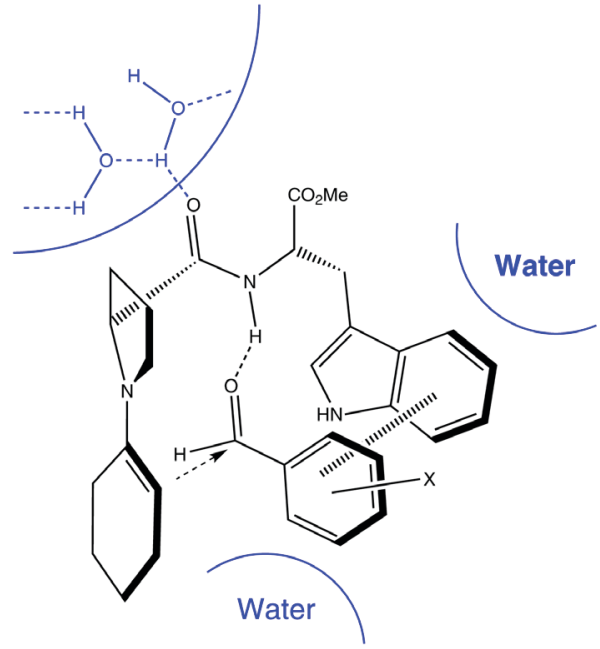

Figure 6. Proposed transition state model of the aldol reaction catalyzed by $(S, S)-44$.

a greater level of sustainability in chemical reactions in general.

\section{Thiohydantoin (S)-Proline Derivatives as Organocatalyst}

Kokotos et al. ${ }^{111}$ have synthesized diverse $(S)$-proline derivatives containing a thiohydantoin fragment and tested them as organocatalyst in the asymmetric Michael addition reaction. Similarly, in our research group, a different series of thiohydantoins derived from proline was prepared by means of the synthetic route presented in Scheme $6 .{ }^{112}$ Various techniques including X-ray diffraction structural analysis, ${ }^{13} \mathrm{C}$ NMR and MS-TOF (time-of-flight mass spectrometry) helped confirm the formation of the thiohydantoin scaffold rather than isothioureas, a result that was explained in terms of the hard and soft acid and base theory (HSAB theory) proposed by Pearson, ${ }^{113}$ considering that nitrogen (a hard nucleophile) preferably attacks the carbonyl group (a hard electrophile). ${ }^{114}$ These thiohydantoin derivatives were tested as organocatalysts in the asymmetric Michael reaction, and variables such as solvents, acidic additives and temperature were modified in order to find the most optimal conditions. The importance of solvent-free reaction conditions to maximize the suitable intermolecular interactions affording the desired stereocontrol constitute salient features of these catalytic systems (Scheme 7).

\section{Diaza-Analogues of gem-Diphenyl Prolinols and their Application as Organocatalysts}

$\alpha, \alpha$-Diarylprolinol derivatives are well-established families of catalysts, which are widely used to promote diverse asymmetric reactions. ${ }^{63}$ The enantioinduction 


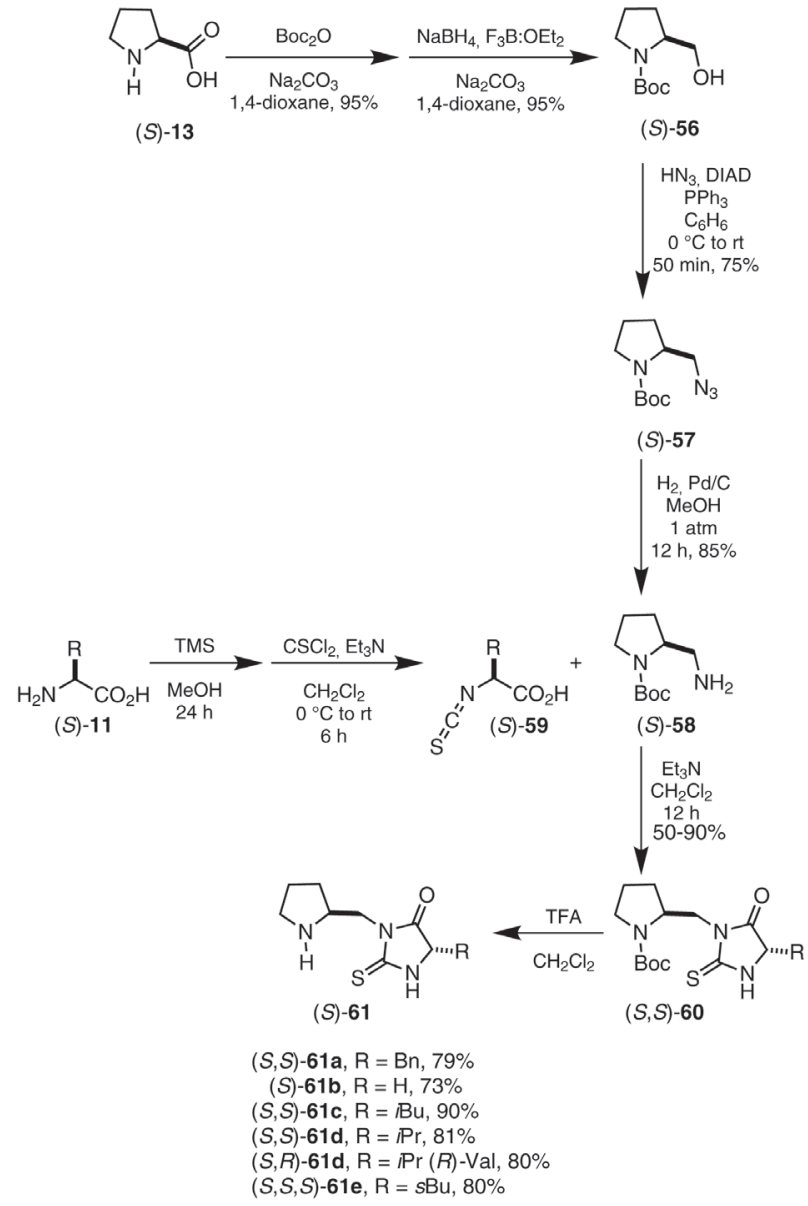

Scheme 6. General synthetic route to obtain the $(S)$-proline-derived amino thiohydantoins 61a-e.

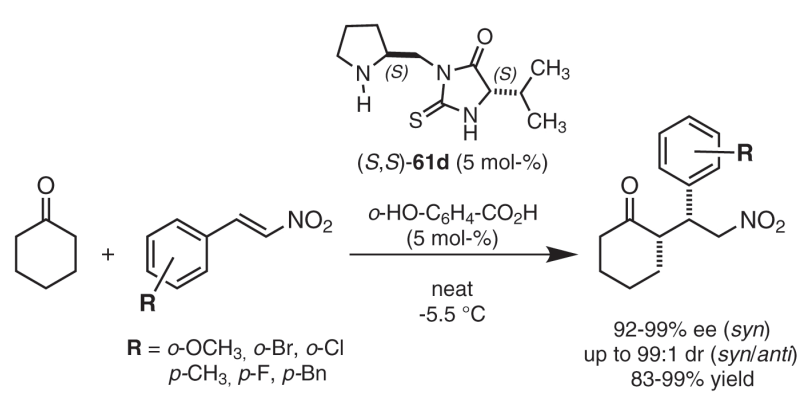

Scheme 7. Michael addition reaction catalyzed by thiohydantoin $(S, S)$-61d under solvent-free conditions.

generated from these catalysts is mainly due to the gem-diphenyl carbinol fragment, that may be considered as a chiral amplifier. ${ }^{15}$ Hence, the synthesis of chiral diaza analogues of the classical and privileged amino alcohols seemed an evident goal to address in the development of alternative chiral ligands. In this regard, in our group there has been a continuous interest in the synthesis of $\alpha$-phenyl and $\alpha, \alpha$-diphenyl prolinamines and its derivatives. ${ }^{116}$

In particular, in 2008 we accomplished the substitution of the tertiary hydroxyl group within $N$-benzyl $\alpha, \alpha$-diphenylprolinol $(S)$-64-I by an azide ion $[(S)-\mathbf{6 5 - I}]$ in the presence of high concentrations of sulfuric acid (to provoke $\mathrm{S}_{\mathrm{N}} 1$ type reaction, see Scheme 8). The resulting aminoazide was reduced and deprotected to obtain diamine $(S)-68 \mathbf{a}$, that was used as precursor of a diazaborolidine, in turn tested as catalyst in the asymmetric reduction of prochiral ketones. ${ }^{117}$ An alternative route was developed to carry out the $\mathrm{OH} \rightarrow \mathrm{N}_{3}$ substitution directly from (S)-diphenyl(pyrrolidin-2-yl)methanol (S)-64-II by using trifluoroacetic acid, this in order to afford the pyrrolidinederived azide (S)-65-II, which could be $N$-Boc protected and then reduced to the diamine derivative $(S)$-66. The $\mathrm{N}$-Boc protecting group on the pyrrolidine nitrogen allowed the functionalization of the primary amino group into various amide, alkylated amine, sulfonamide and triazole derivatives [(S)-68a-f] (Scheme 8). In each case, carefully controlled conditions were required to generate the desired derivatives from the sterically hindered benzhydrylamine moiety. ${ }^{118}$

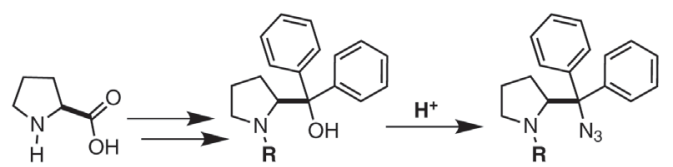

(S)-13
(S)-64-I, $\mathbf{R}=\mathrm{Bn}$ (S)-64-II, R = H

(S)-65-I, $\mathbf{R}=\mathrm{Bn}$ $\mathrm{H}^{+}: \mathrm{H}_{2} \mathrm{SO}_{4}\left(50-70 \%\right.$ aq.) $-\mathrm{CHCl}_{3}$

\section{(S) $-65-\mathrm{II}, \mathbf{R}=\mathrm{H}$} $\mathrm{H}^{+}: \mathrm{CF}_{3} \mathrm{CO}_{2} \mathrm{H}$

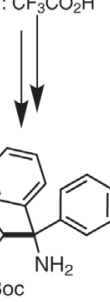

(S)-66

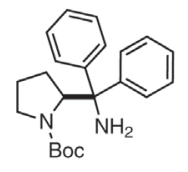

(S)-68a-f
(S)-67

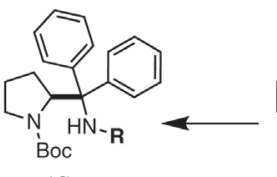

$-\mathbf{R}:-\mathrm{H}(\mathbf{a}),-\mathrm{Ts}(\mathbf{b}),-\mathrm{Bz}(\mathbf{c})$ $-A c(d),-B n(e),-E t(f)$

Scheme 8. Synthesis and derivatization of amino azides $(S)-65-I$ and (S)-65-II.

It is worth mentioning that by-product $(S)$-68d' formed as a consequence of the Thorpe-Ingold effect. ${ }^{119}$ The enantiomeric purity of amidine $(S)$-68d' was evaluated by HPLC (Figure 7) in order to correlate the ee with the enantiopurity of amino azide $(S)-\mathbf{6 5}$-II and its derivatives.

Chiral diamines $(S)$-65-II and $(S)$-68a, b,e,f were evaluated as bifunctional organocatalysts in the asymmetric Michael addition (Table 4). (S)-2-(Azidodiphenylmethyl) pyrrolidine $(S)$-65-II was identified as the most efficient organocatalyst. As it could be anticipated, stereocontrol is mainly directed by steric hindrance. Diamine $(S)$-68a was the only derivative where hydrogen bonds apparently play a significant role according to the stereoselectivity observed (Figure 8). 


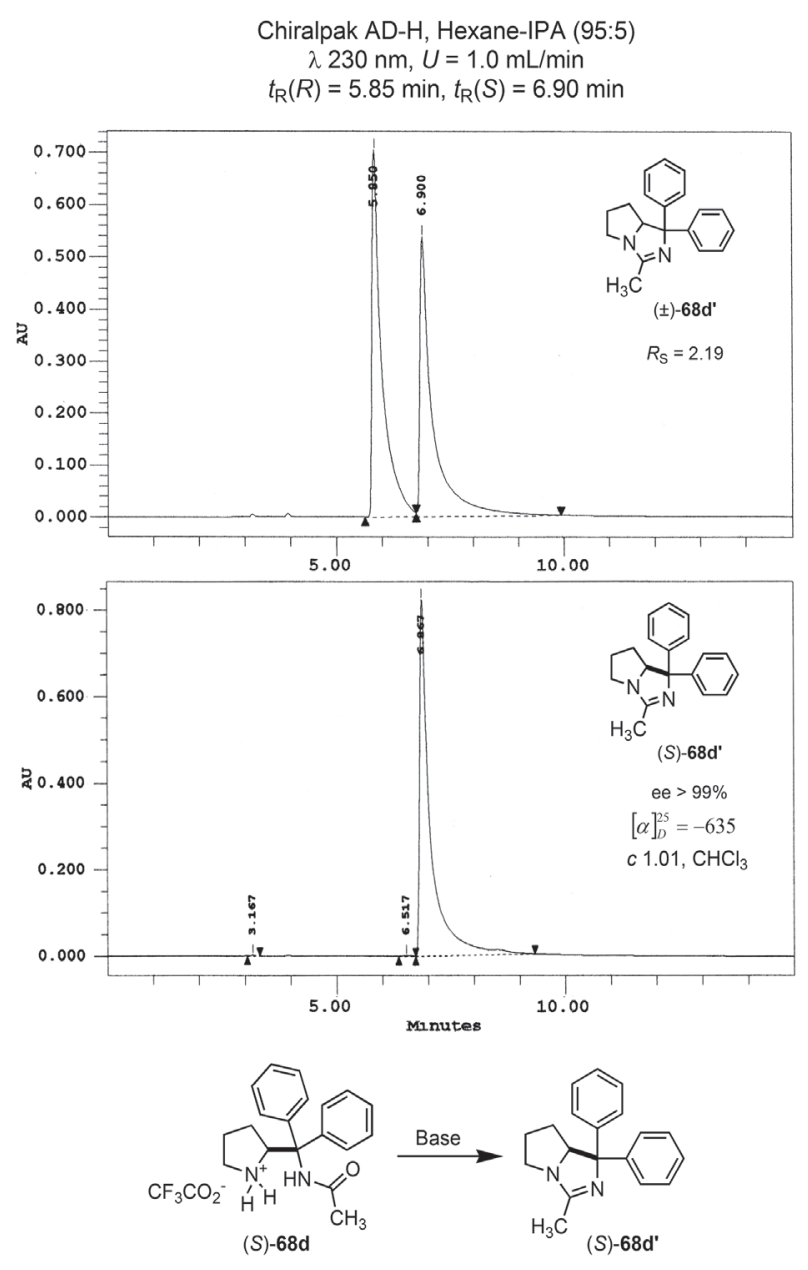

Figure 7. Confirmation of enantiopurity of a derivative obtained from azide $(S)$-65-II. The absolute configuration of (S)-68d' was also corroborated by X-ray diffraction analysis.
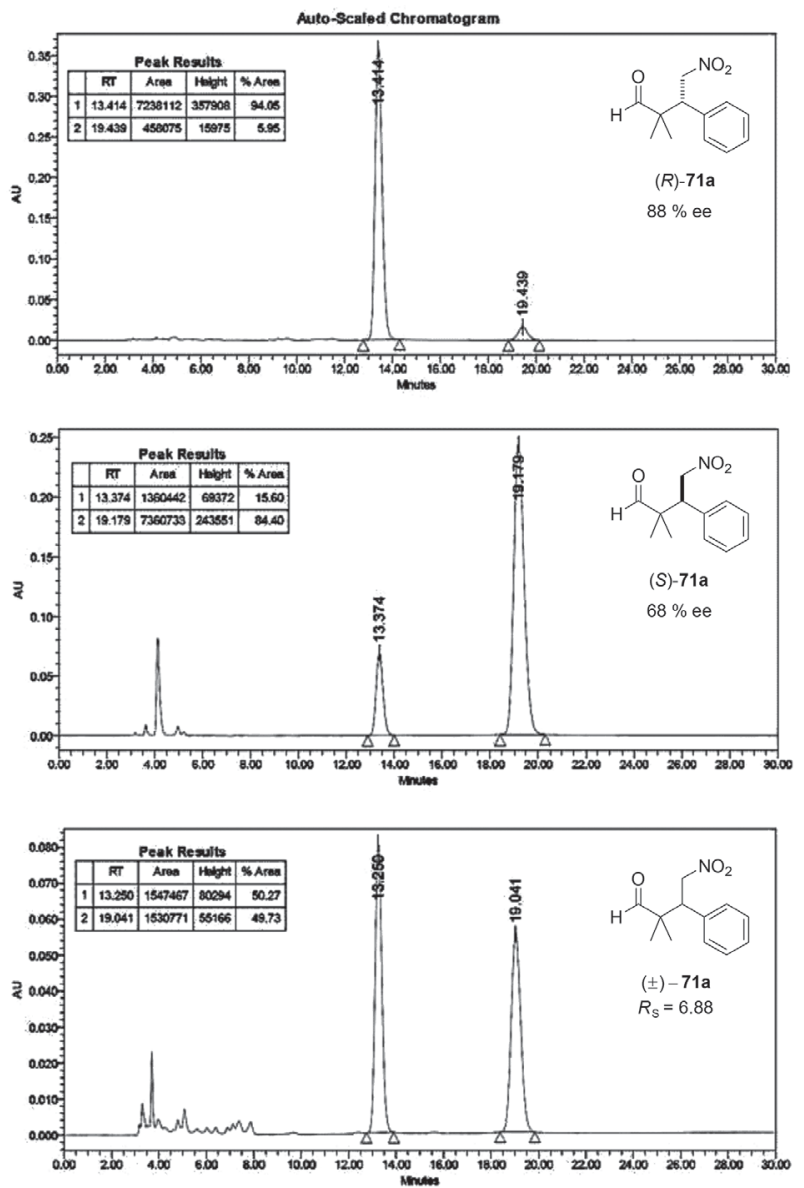

Figure 8. Chromatograms corresponding to Michael adduct $(R)-71 \mathbf{a}$ generated from the reaction promoted by azide $(S)$-65-II, $(S)$-71a obtained with moderate ee from catalysis with diamine $(S)-\mathbf{6 8 a}$ a, and comparison with the racemic mixture. Chiralcel OD-H, Hex:IPA (95:5), $\mathrm{U}=0.8 \mathrm{~mL} \mathrm{~min}^{-1}, \lambda=210 \mathrm{~nm}, \mathrm{t}_{\mathrm{R}(R)}=13.4 \mathrm{~min}, \mathrm{t}_{\mathrm{R}(S)}=19.2 \mathrm{~min}$.

Table 4. Asymmetric Michael reaction catalyzed by pyrrolidine derivatives

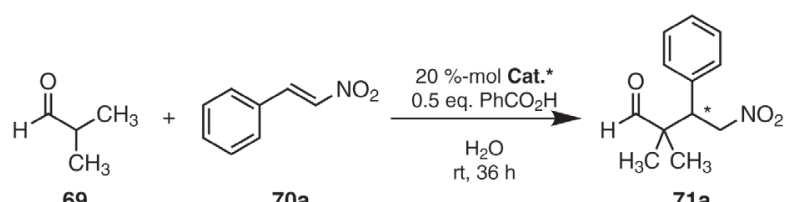

\begin{tabular}{|c|c|c|c|c|}
\hline entry & Catalyst & Yield / \% & e.r. ${ }^{\mathrm{a}}(\mathrm{ee} / \%)$ & Configuration $^{c}$ \\
\hline 1 & $(S)-\mathbf{6 8 a}$ & 57 & $84: 16(68)^{\mathrm{b}}$ & $(S)$ \\
\hline 2 & $(S)-68 \mathbf{a}$ & 98 & $80: 20(60)$ & $(S)$ \\
\hline 3 & $(S)-65-\mathbf{I I}$ & 70 & $95: 5(90)$ & $(R)$ \\
\hline 4 & $(S)-65-\mathbf{I I}$ & 87 & $94: 6(88)^{b}$ & $(R)$ \\
\hline 5 & $(S)-68 \mathbf{b}$ & 7 & $83: 17$ (66) & $(R)$ \\
\hline 6 & $(S)-68 \mathbf{e}$ & 50 & $94: 6(88)$ & $(R)$ \\
\hline 7 & $(S)-68 f$ & 32 & $93: 6(86)$ & $(R)$ \\
\hline
\end{tabular}

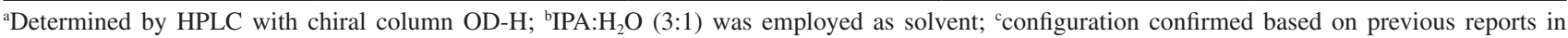
literature. ${ }^{120}$ e.r.: enantiomeric ratio. 
Table 5. Salient examples of Michael adducts generated by azide $(S)-\mathbf{6 5}$-II

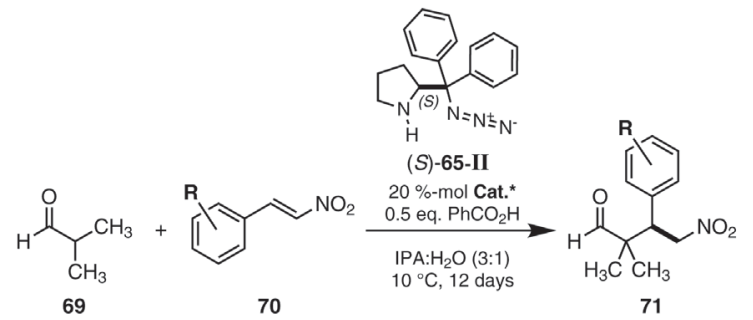

\begin{tabular}{|c|c|c|c|c|c|c|c|c|c|c|}
\hline entry & R- & Yield / \% & e.r. & ee $/ \%$ & {$[\alpha]_{\mathrm{D}}^{25}\left(c 1.0, \mathrm{CHCl}_{3}\right)$} & Lit. $[\alpha]_{\mathrm{D}}^{25}\left(c, \mathrm{CHCl}_{3}\right)$ & Product $^{\mathrm{a}}$ & $\begin{array}{c}\text { Chromatographic } \\
\text { conditions }\end{array}$ & $\begin{array}{l}\text { Resolution } \\
\text { factor }\left(\mathrm{R}_{\mathrm{S}}\right)\end{array}$ & $\mathrm{t}_{\mathrm{R}} / \min$ \\
\hline 1 & $p-\mathrm{CH}_{3-}$ & 94 & $96: 4$ & 92 & +3.0 & $+4.9\left(c 0.49, \mathrm{CHCl}_{3}\right)^{121}$ & $(R)-71 \mathbf{b}$ & Chiralcel OD-H & 6.62 & $\begin{array}{l}12.5(R) \\
17.3(S)\end{array}$ \\
\hline 2 & $p-\mathrm{CH}_{3} \mathrm{O}-$ & 63 & $95: 5$ & 90 & -1.4 & $-3.0\left(c 1.0, \mathrm{CHCl}_{3}\right)^{122}$ & $(R)-71 \mathrm{c}$ & 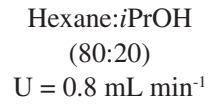 & 7.93 & $\begin{array}{l}16.2(R) \\
25.3(S)\end{array}$ \\
\hline 3 & $m-\mathrm{Cl}-$ & 81 & $97: 3$ & 94 & +8.0 & $+10.0\left(c 1.0, \mathrm{CHCl}_{3}\right)^{121}$ & $(R)-71 d$ & $\lambda=210 \mathrm{~nm}$ & 8.29 & $\begin{array}{l}17.5(R) \\
28.2(S)\end{array}$ \\
\hline
\end{tabular}

a Stereochemistry assigned by comparing optical rotation from literature, which is in accordance with the observed stereoinduction promoted by steric hindrance. e.r.: enantiomeric ratio; $\mathrm{U}$ : volumetric flow rate of the mobile phase; $\mathrm{t}_{\mathrm{R}}$ : retention time.
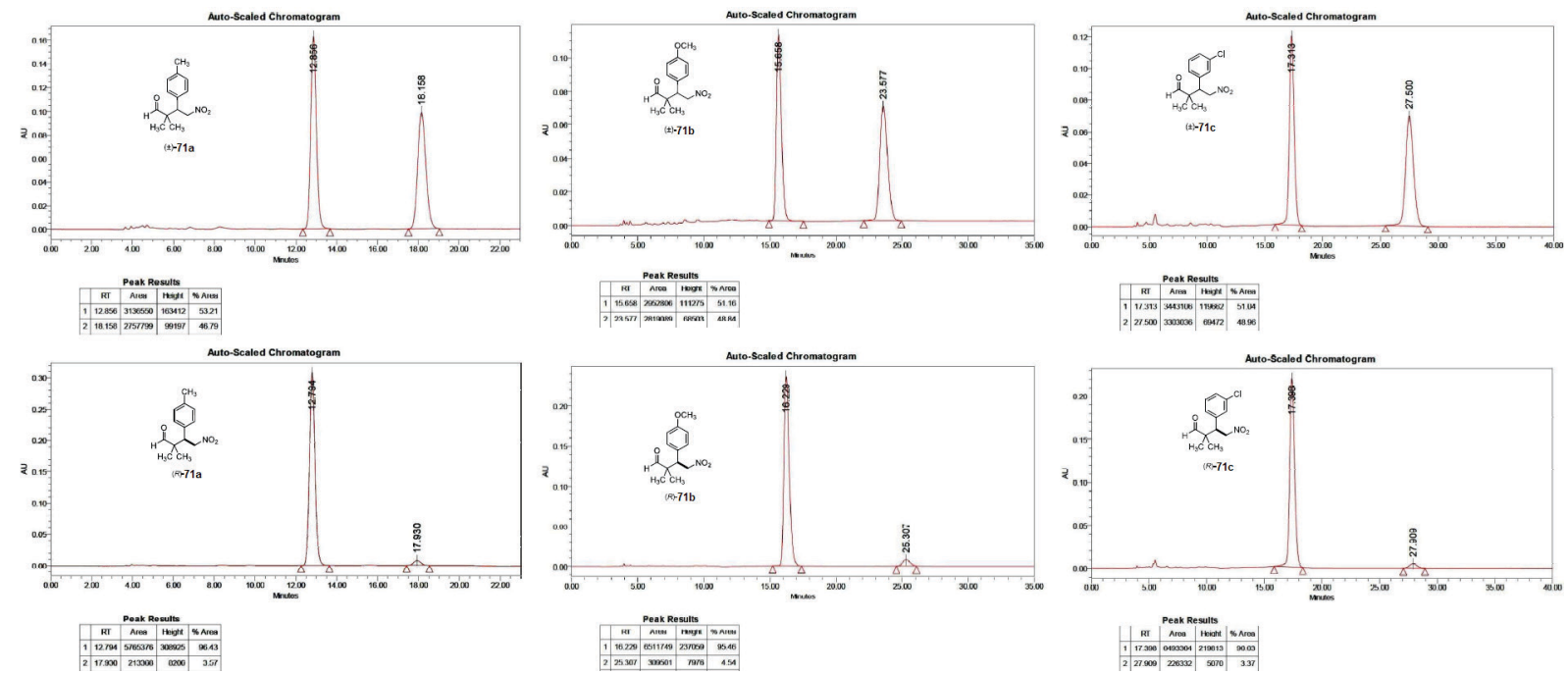

Figure 9. Chromatograms corresponding to Michael adduct $(R)-\mathbf{7 1 a - c}$ (bottom, left to right) generated from the reaction promoted by azide $(S)$-65-II, these are compared with their corresponding racemic mixture ( \pm )-71a-c (top).

Table 5 presents selected results regarding the enantioselectivities observed with diverse substrates by employing organocatalyst (S)-65-II. In addition, Figure 9 includes chromatograms pertinent to Table 5 .

\section{Conclusions}

The development of chiral stationary phases since the second half of the twentieth century constitutes an indispensable tool that is frequently taken by granted. Nevertheless, without chiral chromatography, the enormous advance registered in several areas of asymmetric synthesis such as organocatalysis would not have been possible.
Diverse standard compounds such as $\alpha$-amino acids, Tröger's base, benzoin, Pirkle's alcohol, among others, have been conventionally employed to evaluate newly designed chiral selectors. Continuing studies with available techniques have also allowed a better understanding of specific mechanisms of chiral recognition.

Organocatalysis has been a buoyant area in asymmetric synthesis during the last 15 years. An immense quantity of data used to evaluate new ligands and reactions is available thanks to the employment of chiral chromatography. It would be interesting to develop "tailor-made" chiral selectors for e.g. chiral Michael adducts, which should be feasible considering the principle of reciprocity (Pirkle 
concept) employed in the design of selectors. Combined techniques such as HPLC-circular dichroism (CD) together with quantum chemical CD calculations ${ }^{123}$ will help evaluate stereoinduction from a newly developed ligand as potential organocatalyst.

\section{Acknowledgments}

The authors acknowledge financial support via grant CB-2013/220945 from the National Council of Science and Technology (CONACYT, Mexico). The authors also thank Dr Carmen Giovana Granados Ramirez for helpful technical assistance about HPLC.

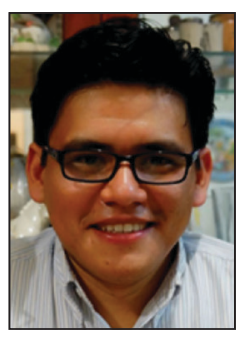

Jorge Vargas-Caporali was born in Tabasco (Mexico) in 1984, he received his bachelor degree in Chemical Engineering (2007) by the ITVh. He carried out some short research stays at the IBBM-UMontpellier (2011) and at the Institut für Organische ChemieFAU-Erlangen-Nürnberg (2014), then completed his PhD in Chemical Sciences (2015) at the Chemistry Department of CINVESTAV-IPN, under the guidance of Prof Juaristi, and he held a postdoctoral research position in the same group (2015-2017). His research interests are focused on the synthesis of chiral diamino derivatives and their evaluation as catalysts in asymmetric synthesis.

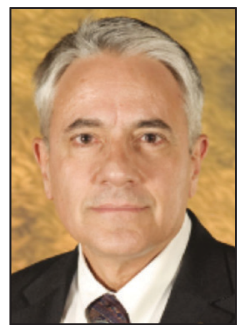

Eusebio Juaristi was born in Querétaro (Mexico) in 1950 and studied Chemistry at Instituto Tecnológico de Monterrey (BSc) and at the University of North Carolina in Chapel Hill (PhD). Following postdoctoral stays in the University of California-Berkeley and Syntex, California, he returned to Mexico in 1979, to the Chemistry Department of CINVESTAV-IPN, where he is currently Emeritus Professor of Chemistry. He has been Visiting Professor at the ETH-Zurich (1985-1986 and 1992-1993), UC-Berkeley (1999-2000) and RWTH-Aachen (2013). In 1998 he received Mexico's Presidential Medal of Science and in 2006 he became a member of El Colegio Nacional, highest academic distinction in Mexico.

\section{References}

1. Rouf, A.; Taneja, S. C.; Chirality 2014, 26, 63; Maltsev, O.
V.; Beletskaya, I. P.; Zlotin, S. G.; Russ. Chem. Rev. 2011, 80, 1067; Hong, B.-C.; Raja, A.; Sheth, V. M.; Synthesis 2015, 47, 3257; Juaristi, E.; An. Quim. Int. Ed. 1997, 93, 135.

2. de Graaf, C.; Ruijter, E.; Orru, R. V. A.; Chem. Soc. Rev. 2012, 41, 3969; Nájera, C.; Sansano, J. M.; Yus, M.; J. Braz. Chem. Soc. 2010, 21, 377.

3. Flack, H. D.; Chimia 2014, 68, 26; Thompson, A. L.; Watkin, D. J.; Tetrahedron: Asymmetry 2009, 20, 712; Thompson, A. L.; Watkin, D. J.; J. Appl. Crystallogr. 2011, 44, 1017; EscuderoAdán, E. C.; Benet-Buchholz, J.; Ballester, P.; Acta Crystallogr., Sect. B: Struct. Sci., Cryst. Eng. Mater. 2014, B70, 660; Albright, A. L.; White, J. M. In Metabolomics Tools for Natural Product Discovery: Methods and Protocols, Methods in Molecular Biology, vol. 1055; Roessner, U.; Dias, D. A., eds.; Springer Science+Business Media: Heidelberg, Germany, 2013, p. 149.

4. Pirkle, W. H.; Hoover, D. J. In Topics in Stereochemistry, vol. 13; Wilen, S.; Eliel, E., eds.; Wiley: New York, United States, 1982, p. 263; Parker, D.; Chem. Rev. 1991, 91, 1441; Wenzel, T. J.; Chisholm, C. D.; Chirality 2011, 23, 190; Wenzel, T. J.; Chisholm, C. D.; Prog. Nucl. Magn. Reson. Spectrosc. 2011, 59, 1; Uccello-Barretta, G.; Balzano, F. In Topics in Current Chemistry, vol. 341; Schurig, V., ed.; Springer-Verlag: Heidelberg, Germany, 2013, p. 69.

5. Allenmark, S.; Schurig, V.; J. Mater. Chem. 1997, 7, 1955; Okamoto, Y.; Ikai, T.; Chem. Soc. Rev. 2008, 37, 2593; Ward, T. J.; Ward, K. D.; Anal. Chem. 2010, 82, 4712; Cavazzini, A.; Pasti, L.; Massi, A.; Marchetti, N.; Dondi, F.; Anal. Chim. Acta 2011, 706, 205.

6. He, Y.; Wang, B.; Dukor, R. K.; Nafie, L. A.; Appl. Spectrosc. 2011, 65, 699.

7. Heravi, M. M.; Zadsirjan, V.; Tetrahedron: Asymmetry 2013, 24, 1149; Davies, S. G.; Fletcher, A. M.; Thomson, J. E.; Chem. Commun. 2013, 49, 8586.

8. Bauer, E. B.; Chem. Soc. Rev. 2012, 41, 3153; Majumdar, K. C.; Sinha, B.; RSC Adv. 2014, 4, 8085; Li, Y.-Y.; Yu, S.-L.; Shen, W.-Y.; Gao, J.-X.; Acc. Chem. Res. 2015, 48, 2587; Bigler, R.; Huber, R.; Mezzetti, A.; Synlett 2016, 27, 831; Pellissier, H.; Chem. Rev. 2016, 116, 14868; Oloo, W. N.; Que Jr., L.; Acc. Chem. Res. 2015, 48, 2612.

9. Reetz, M. T.; Angew. Chem., Int. Ed. 2011, 50, 138; Reetz, M. T.; J. Org. Chem. 2009, 74, 5767; Hall, M.; Bommarius, A. S.; Chem. Rev. 2011, 111, 4088; Denard, C. A.; Hartwig, J. F.; Zhao, H.; ACS Catal. 2013, 3, 2856.

10. Kaur, J.; Chauhan, P.; Singh, S.; Chimni, S. S.; Chem. Rec. 2017, 17, 1; Mukherjee, S.; Yang, J. W.; Hoffmann, S.; List, B.; Chem. Rev. 2007, 107, 5471; Pihko, P. M.; Majander, I.; Erkkilä, A. In Topics in Current Chemistry, vol. 291; List, B., ed.; Springer: Heidelberg, Germany, 2009, p. 145; Melchiorre, P.; Marigo, M.; Carlone, A.; Bartoli, G.; Angew. Chem., Int. Ed. 2008, 47, 6138; Bertelsen, S.; Jørgensen, K. A.; Chem. Soc. Rev. 2009, 38, 2178; Lu, L.-Q.; An, X.-L.; Chen, J.-R.; Xiao, W.-J.; 
Synlett 2012, 23, 490; Scheffler, U.; Mahrwald, R.; Chem. Eur. J. 2013, 19, 14346.

11. Gil-Av, E.; Feibush, B.; Charles-Sigler, R.; Tetrahedron Lett. 1966, 1009; Feibush, B.; Balan, A.; Altman, B.; Gil-Av, E.; J. Chem. Soc., Perkin Trans. 2 1979, 1230; Gil-Av, E.; J. Mol. Evol. 1975, 6, 131; Hare, P. E.; Gil-Av, E.; Science 1979, 204, 1226; Schurig, V.; Isr. J. Chem. 2016, 56, 890.

12. Francotte, E. R.; J. Chromatogr. A 2001, 906, 379.

13. Cagliero, C.; Sgorbini, B.; Cordero, C.; Liberto, E.; Rubiolo, P.; Bicchi, C.; Isr. J. Chem. 2016, 56, 925; Sicoli, G.; Kreidler, D.; Czesla, H.; Hopf, H.; Schurig, V.; Chirality 2009, 21, 183.

14. Ali, I.; Kumerer, K.; Aboul-Enein, Y.; Chromatographia 2006, 63,295 .

15. Scriba, G. K. E.; Chromatographia 2012, 75, 815; Scriba, G. K. E.; J. Chromatogr. A 2016, 1467, 56; Lämmerhofer, M.; J. Chromatogr. A 2010, 1217, 814; Pirkle, W. H.; Pochapsky, T. C.; Chem. Rev. 1989, 89, 347.

16. Davankov, V. A.; J. Chromatogr. A 1994, 666, 55.

17. Hyun, M. H.; J. Chromatogr. A 2016, 1467, 19; Hyun, M. H.; Bull. Korean Chem. Soc. 2005, 26, 1153.

18. Crini, G.; Morcellet, M.; J. Sep. Sci. 2002, 25, 789; Zhang, W.; Tang, Y.; Xu, J.; Sun, J.; Lang, W.; Bull. Korean Chem. Soc. 2016, 37, 877; Ilisz, I.; Berkecz, R.; Forró, E.; Fülöp, F.; Armstrong, D. W.; Péter, A.; Chirality 2009, 21, 339.

19. Breitbach, A. S.; Lim, Y.; Xu, Q.-L.; Kürti, L.; Armstrong, D. W.; Breitbach, Z. S.; J. Chromatogr. A 2016, 1427, 45.

20. Ilisz, I.; Pataj, Z.; Aranyi, A.; Péter, A.; Sep. Purif. Rev. 2012, 41, 207; Ilisz, I.; Berkecz, R.; Péter, A.; J. Chromatogr. A 2009, 1216, 1845; Ilisz, I.; Berkecz, R.; Péter, A.; J. Sep. Sci. 2006, 29, 1305.

21. Fernandes, C.; Phyo, Y. Z.; Silva, A. S.; Tiritan, M. E.; Kijjoa, A.; Pinto, M. M. M.; Sep. Purif. Rev. 2017, DOI 10.1080/15422119.2017.1326939; Fernandes, C.; Tiritan, M. E.; Pinto, M.; Chromatographia 2013, 76, 871; Ismail, O. H.; Pasti, L.; Ciogli, A.; Villani, C.; Kocergin, J.; Anderson, S.; Gasparrini, F.; Cavazzini, A.; Catani, M.; J. Chromatogr. A 2016, 1466, 96; Gasparrini, F.; Misiti, D.; Villani, C.; J. Chromatogr. A 2001, 906, 35; Welch, C. J.; J. Chromatogr. A 1994, 666, 3.

22. Ilisz, I.; Grecsó, N.; Misicka, A.; Tymecka, D.; Lázár, L.; Lindner, W.; Péter, A.; Molecules 2015, 20, 70; Ilisz, I.; Grecsó, N.; Palkó, M.; Fülöp, F.; Lindner, W.; Péter, A.; J. Pharm. Biomed. Anal. 2014, 98, 130; Ilisz, I.; Pataj, Z.; Gecse, Z.; Szakonyi, Z.; Fülöp, F.; Lindner, W.; Péter, A.; Chirality 2014, 26, 385; Péter, A.; Grecsó, N.; Tóth, G.; Fülöp, F.; Lindner, W.; Ilisz, I.; Isr. J. Chem. 2016, 56, 1042; Lämmerhofer, M.; Anal. BioAnal. Chem. 2014, 406, 6095.

23. Ilisz, I.; Aranyi, A.; Pataj, Z.; Péter, A.; J. Chromatogr. A 2012, 1269, 94.

24. Sellergren, B.; J. Chromatogr. A 2001, 906, 227; Yamamoto, C.; Okamoto, Y.; Bull. Chem. Soc. Jpn. 2004, 77, 227; Marty, J. D.; Mauzac, M.; Adv. Polym. Sci. 2005, 172, 1; Alexander,
C.; Andersson, H. S.; Andersson, L. I.; Ansell, R. J.; Kirsch, N.; Nicholls, I. A.; O’Mahony, J.; Whitcombe, M. J.; J. Mol. Recognit. 2006, 19, 106; Shen, J.; Okamoto, Y.; Chem. Rev. 2016, 116, 1094; Morioka, K.; Suito, Y.; Isobe, Y.; Habaue, S.; Okamoto, Y.; J. Polym. Sci., Part A: Polym. Chem. 2003, 41, 3354.

25. Chankvetadze, B.; J. Chromatogr. A 2012, 1269, 26; Ikai, T.; Okamoto, Y.; Chem. Rev. 2009, 109, 6077.

26. Bi, C.; Zheng, X.; Azaria, S.; Beeram, S.; Li, Z.; Hage, D. S.; Separations 2016, 3, 27, DOI 10.3390/separations3030027; Sanghvi, M.; Moaddel, R.; Wainer, I. W.; J. Chromatogr. A 2011, 1218, 8791; Haginaka, J.; J. Chromatogr. B 2008, 875, 12; Millot, M. C.; J. Chromatogr. B 2003, 797, 131; Haginaka, J.; J. Chromatogr. A 2001, 906, 253.

27. Hyun, M. H.; Ryoo, J.-J.; J. Liq. Chromatogr. Relat. Technol. 1996, 19, 2635.

28. Hyun, M. H.; Chirality 2015, 27, 576.

29. Berthod, A.; Chen, X.; Kullman, J. P.; Armstrong, D. W.; Gasparrini, F.; D’Acquarica, I.; Villani, C.; Carotti, A.; Anal. Chem. 2000, 72, 1767; Péter, A.; Árki, A.; Tourwé, D.; Forró, E.; Fülöp, F.; Armstrong, D. W.; J. Chromatogr. A 2004, 1031, 159; Pataj, Z.; Berkecz, R.; Ilisz, I.; Misicka, A.; Tymecka, D.; Fülöp, F.; Armstrong, D. W.; Péter, A.; Chirality 2009, 21, 787.

30. Pirkle, W. H.; Welch, C. J.; Burke, J. A.; Lamm, B.; Anal. Proc. 1992, 29, 225; Pirkle, W. H.; Welch, C. J.; Lamm, B.; J. Org. Chem. 1992, 57, 3854; Pirkle, W. H.; Liu, Y.; J. Chromatogr. A 1996, 736, 31; ibid. 749, 19; Pirkle, W. H.; Welch, C. J.; J. Chromatogr. A 1994, 683, 347.

31. Pirkle, W. H.; Welch, C. J.; Hyun, M. H.; J. Org. Chem. 1983, 48, 5022; Pirkle, W. H.; Welch, C. J.; J. Org. Chem. 1984, 49, 138; Pirkle, W. H.; Welch, C. J.; Mahler, G. S.; J. Org. Chem. 1984, 49, 2504.

32. Ilisz, I.; Grecsó, N.; Aranyi, A.; Suchotin, P.; Tymecka, D.; Wilenska, B.; Misicka, A.; Fülöp, F.; Lindner, W.; Péter, A.; J. Chromatogr. A 2014, 1334, 44.

33. Chen, X.; Yamamoto, C.; Okamoto, Y.; Pure Appl. Chem. 2007, 79, 1561; Chankvetadze, B. In Chiral Separations: Methods and Protocols, Methods in Molecular Biology, vol. 970; Scriba, G. K. E., ed.; Springer Science+Business Media: Heidelberg, Germany, 2013, p. 81.

34. Rogozhin, S. V.; Davankov, V. A.; Chem. Commun. 1971, 490; Davankov, V. A.; Bochkov, A. S.; Kurganov, A. A.; Roumeliotis, P.; Unger, K. K.; Chromatographia 1980, 13, 677; Yamskov, I. A.; Berezin, B. B.; Davankov, V. A.; Zolotarev, Y. A.; Dostavalov, I. N.; Myasoedov, N. F.; J. Chromatogr. 1981, 217 , 539; Gübitz, G.; Juffmann, F.; Jellenz, W.; Chromatographia 1982, 16, 103; Brückner, H.; Chromatographia 1987, 24, 725; Veigl, E.; Lindner, W.; J. Chromatogr. A 1994, 660, 255; Grobuschek, N.; Schmid, M. G.; Tuscher, C.; Ivanova, M.; Gübitz, G.; J. Pharm. Biomed. Anal. 2002, 27, 599.

35. Hesse, G.; Hagel, R.; Chromatographia 1973, 6, 277. 
36. Stewart, K. K.; Doherty, R. F.; Proc. Natl. Acad. Sci. U. S. A. 1973, 70, 2850.

37. Blaschke, G.; Chem. Ber. 1974, 107, 237.

38. Dotsevi, G.; Sogah, Y.; Cram, D. J.; J. Am. Chem. Soc. 1975, 97 , 1259; Sousa, L. R.; Sogah, G. D. Y.; Hoffman, D. H.; Cram, D. J.; J. Am. Chem. Soc. 1978, 100, 4569; Sogah, G. D. Y.; Cram, D. J.; J. Am. Chem. Soc. 1979, 101, 3035; Hyun, M. H.; Han, S. C.; Lipshutz, B. H.; Shin, Y.-J.; Welch, C. J.; J. Chromatogr. A 2001, 910, 359; Hyun, M. H.; Han, S. C.; Lipshutz, B. H.; Shin, Y.-J.; Welch, C. J.; J. Chromatogr. A 2002, 959, 75; Hyun, M. H.; Tan, G.; Cho, Y. J.; Biomed. Chromatogr. 2005, 19, 208.

39. Mikeš, F.; Boshart, G.; Gil-Av, E.; J. Chromatogr. 1976, 122, 205.

40. Pirkle, W. H.; House, D. W.; J. Org. Chem. 1979, 44, 1957; Pirkle, W. H.; House, D. W.; Finn, J. M.; J. Chromatogr. 1980, 192, 143.

41. Pirkle, W. H.; Finn, J. M.; J. Org. Chem. 1981, 46, 2935; Pirkle, W. H.; Schreiner, J. L.; J. Org. Chem. 1981, 46, 4988; Pirkle, W. H.; Finn, J. M.; Schreiner, J. L.; Hamper, B. C.; J. Am. Chem. Soc. 1981, 103, 3964.

42. Hermansson, J.; J. Chromatogr. 1984, 298, 67.

43. Okamoto, Y.; Kawashima, M.; Hatada, K.; J. Am. Chem. Soc. 1984, 106, 5357; Okamoto, Y.; Kawashima, M.; Yamamoto, K.; Hatada, K.; Chem. Lett. 1984, 739; Okamoto, Y.; Kawashima, M.; Hatada, K.; J. Chromatogr. 1986, 363, 173; Ichida, A.; Shibata, T.; Okamoto, Y.; Yuki, Y.; Namikoshi, H.; Toga, Y.; Chromatographia 1984, 19, 280; Shibata, T.; Okamoto, Y.; Ishii, K.; J. Liq. Chromatogr. 1986, 9, 313; Okamoto, Y.; Yashima, E.; Angew. Chem., Int. Ed. 1998, 37, 1020; Kubota, T.; Yamamoto, C.; Okamoto, Y.; J. Am. Chem. Soc. 2000, 122, 4056.

44. Allenmark, S.; Bomgren, B.; Borén, H.; J. Chromatogr. 1984, 617.

45. Armstrong, D. W.; Ward, T. J.; Armstrong, R. D.; Beesly, T. E.; Science 1986, 232, 1132.

46. Pirkle, W. H.; Lee, W.; Bull. Korean Chem. Soc. 1998, 19, 1277; Pirkle, W. H.; Welch, C. J.; Tetrahedron: Asymmetry 1994, 5, 777; Pirkle, W. H.; Spence, P. L.; Chirality 1998, 10, 430; Pirkle, W. H.; Spence, P. L.; J. Chromatogr. A 1997, 775, 81; Yu, J. J.; Hyun, M. H.; Armstrong, D. W.; Breitbach, Z. S.; Ryoo, J. J.; Bull. Korean Chem. Soc. 2015, 36, 723.

47. Armstrong, D. W.; Tang, Y.; Chen, S.; Zhou, Y.; Bagwill, C.; Chen, J.-R.; Anal. Chem. 1994, 66, 1473; Berthod, A.; Chirality 2009, 21, 167; Péter, A.; Árki, A.; Vékes, E.; Tourwé, D.; Lázár, L.; Fülöp, F.; Armstrong, D. W.; J. Chromatogr. A 2004, 1031, 171; Pataj, Z.; Ilisz, I.; Berkecz, R.; Misicka, A.; Tymecka, D.; Fülöp, F.; Armstrong, D. W.; Péter, A.; J. Sep. Sci. 2008, 31, 3688; D’Acquarica, I.; Gasparrini, F.; Misiti, D.; Zappia, G.; Cimarelli, C.; Palmieri, G.; Carotti, A.; Cellamare, S.; Villani, C.; Tetrahedron: Asymmetry 2000, 11, 2375; Ilisz, I.; Grecsó, N.; Forró, E.; Fülöp, F.; Armstrong, D. W.; Péter, A.; J. Pharm. Biomed. Anal. 2015, 114, 312.
48. Lämmerhofer, M.; Lindner, W.; J. Chromatogr. A 1996, 741, 33.

49. Francotte, E.; WO1996027615 A1 1996.

50. Machida, Y.; Nishi, H.; Nakamura, K.; Nakai, H.; Sato, T.; J. Chromatogr. A 1998, 805, 85; Hyun, M. H.; Jin, J. S.; Lee, W.; J. Chromatogr. A 1998, 822, 155; Park, J. Y.; Jin, K. B.; Hyun, M. H.; Chirality 2012, 24, 427; Jin, K. B.; Kim, H. E.; Hyun, M. H.; Chirality 2014, 26, 272; Ahn, S. A.; Hyun, M. H.; Chirality 2015, 27, 268; Hyun, M. H.; Kim, D. H.; Chirality 2004, 16, 294; Hyun, M. H.; Cho, Y. J.; Kim, J. A.; Jin, J. S.; J. Liq. Chromatogr. Relat. Technol. 2003, 26, 1083; Hyun, M. H.; Song, Y.; Choo, Y. J.; Choi, H. J.; Chirality 2008, 20, 325; Hyun, M. H.; Song, Y.; Choo, Y. J.; Choi, H. J.; J. Sep. Sci. 2007, 30, 2539; Berkecz, R.; Ilisz, I.; Misicka, A.; Tymecka, D.; Fülöp, F.; Choi, H. J.; Hyun, M. H.; Péter, A.; J. Sep. Sci. 2009, 32, 981; Ilisz, I.; Pataj, Z.; Berkecz, R.; Misicka, A.; Tymecka, D.; Fülöp, F.; Choi, H. J.; Hyun, M. H.; Péter, A.; J. Chromatogr. A 2010, 1217, 1075.

51. Hoffmann, C. V.; Pell, R.; Lämmerhofer, M.; Lindner, W.; Anal. Chem. 2008, 80, 8780; Keunchkarian, S.; Osorio Grisales, J.; Padró, J. M.; Boeris, S.; Castells, C. B.; Chirality 2012, 24, 512; Sardella, R.; Lämmerhofer, M.; Natalini, B.; Lindner, W.; Chirality 2008, 20, 571.

52. Sun, P.; Wang, C.; Breitbach, Z. S.; Zhang, Y.; Armstrong, D. W.; Anal. Chem. 2009, 81, 10215.

53. Cf. Vogel, P.; Lam, Y.-H.; Simon, A.; Houk, K. N.; Catalysis 2016, 6, 128, doi:10.3390/catal6090128.

54. Cf. de Figuereido, R. M.; Christmann, M.; Eur. J. Org. Chem. 2007, 2575; Ostwald, W.; Z. Phys. Chem. 1900, 32, 509.

55. Hajos, Z. G.; Parrish, D. R.; J. Org. Chem. 1974, 39, 1615; Eder, U.; Sauer, G.; Wiechert, R.; Angew. Chem., Int. Ed. Engl. 1971, 10, 496.

56. List, B.; Lerner, R. A.; Barbas III, C. F.; J. Am. Chem. Soc. 2000, 122, 2395.

57. List, B.; Tetrahedron 2002, 58, 5573.

58. Lou, S.; Taoka, B. M.; Ting, A.; Schaus, S. E.; J. Am. Chem. Soc. 2005, 127, 11256; Ting, A.; Lou, S.; Schaus, S. E.; Org. Lett. 2006, 8, 2003; Saaby, S.; Bella, M.; Jørgensen, K. A.; J. Am. Chem. Soc. 2004, 126, 8120.

59. Ibrahem, I.; Zou, W.; Engqvist, M.; Xu, Y.; Córdova, A.; Chem. Eur. J. 2005, 11, 7024; List, B.; Synlett 2001, 1675; Notz, W.; Tanaka, F.; Watanabe, S.-I.; Chowdari, N. S.; Turner, J. M.; Thayumanavan, R.; Barbas III, C. F.; J. Org. Chem. 2003, 68, 9624; Dziedzic, P.; Córdova, A.; Tetrahedron: Asymmetry 2007, 18, 1033.

60. Mangion, I. K.; Northrup, A. B.; MacMillan, D. W. C.; Angew. Chem., Int. Ed. 2004, 43, 6722.

61. Lei, M.; Shi, L.; Li, G.; Chen, S.; Fang, W.; Ge, Z.; Cheng, T.; Li, R.; Tetrahedron 2007, 63, 7892; Shi, L.-X.; Sun, Q.; Ge, Z.-M.; Zhu, Y.-Q.; Cheng, T.-M.; Li, R.-T.; Synlett 2004, 2215; Chen, F.; Huang, S.; Zhang, H.; Liu, F.; Peng, Y.; Tetrahedron 
2008, 64, 9585; Chandrasekhar, S.; Johny, K.; Reddy, C. R.; Tetrahedron: Asymmetry 2009, 20, 1742.

62. Mase, N.; Watanabe, K.; Yoda, H.; Takabe, K.; Tanaka, F.; Barbas III, C. F.; J. Am. Chem. Soc. 2006, 128, 4966; Mase, N.; Nakai, Y.; Ohara, N.; Yoda, H.; Takabe, K.; Tanaka, F.; Barbas III, C. F.; J. Am. Chem. Soc. 2006, 128, 734; Wang, W.; Li, H.; Wang, J.; Tetrahedron Lett. 2005, 46, 5077; Wang, W.; Wang, J.; Li, H.; Angew. Chem., Int. Ed. 2005, 44, 1369; Wang, J.; Li, H.; Zu, L.; Wang, W.; Adv. Synth. Catal. 2006, 348, 425; Zhuang, W.; Saaby, S.; Jørgensen, K. A.; Angew. Chem., Int. Ed. 2004, $43,4476$.

63. Franzén, J.; Marigo, M.; Fielenbach, D.; Wabnitz, T. C.; Kjærsgaard, A.; Jørgensen, K. A.; J. Am. Chem. Soc. 2005, 127, 18296.

64. Alza, E.; Sayalero, S.; Kasaplar, P.; Alma i, D.; Pericàs, M. A.; Chem. Eur. J. 2011, 17, 11585.

65. Maltsev, O. V.; Kucherenko, A. S.; Beletskaya, I. P.; Tartakovsky, V. A.; Zlotin, S. G.; Eur. J. Org. Chem. 2010, 2927.

66. Ni, B.; Zhang, Q.; Dhungana, K.; Headley, A. D.; Org. Lett. 2009, 11, 1037.

67. Xu, D.; Luo, S.; Yue, H.; Wang, L.; Liu, Y.; Xu, Z.; Synlett 2006, 2569.

68. Luo, S.; Li, J.; Zhang, L.; Xu, H.; Cheng, J.-P.; Chem. Eur. J. 2008, 14, 1273.

69. Yan, J.; Wang, L.; Synthesis 2008, 2065.

70. Gruttadauria, M.; Salvo, A. M. P.; Giacalone, F.; Agrigento, P.; Noto, R.; Eur. J. Org. Chem. 2009, 5437.

71. See, for instance: Holland, M. C.; Gilmour, R.; Angew. Chem., Int. Ed. 2015, 54, 3862; Vilaivan, T.; Bhanthumnavin, W.; Molecules 2010, 15, 917; Verkade, J. M. M.; van Hemert, L. J C.; Quaedflieg, P. J. L.; Rutjes, F. P. J.; Chem. Soc. Rev. 2008, 37, 29; Takemoto, Y.; Stadler, M. In Comprehensive Chirality, vol. 6; Maruoka, K., ed.; Elsevier: Oxford, United Kingdom, 2012, p. 37; Raj, M.; Singh, V. K.; Chem. Commun. 2009, 6687.

72. For example, various studies on the catalytic mechanism displayed by the Jørgensen-Hayashi organocatalyst in asymmetric Michael additions have been compiled: PatoraKomisarska, K.; Benohoud, M.; Ishikawa, H.; Seebach, D.; Hayashi, Y.; Helv. Chim. Acta 2011, 94, 719; Burés, J.; Armstrong, A.; Blackmond, D. G.; J. Am. Chem. Soc. 2011, 133 , 8822; Burés, J.; Armstrong, A.; Blackmond, D. G.; J. Am. Chem. Soc. 2012, 134, 6741; Burés, J.; Armstrong, A.; Blackmond, D. G.; Acc. Chem. Res. 2016, 49, 214; Sahoo, G.; Rahaman, H.; Madarász, Á.; Pápai, I.; Melarto, M.; Valkonen, A.; Pihko, P. M.; Angew. Chem., Int. Ed. 2012, 51, 13144; Seebach, D.; Sun, X.; Sparr, C.; Ebert, M.-O.; Schweizer, W. B.; Beck, A. K.; Helv. Chim. Acta 2012, 95, 1064; Seebach, D.; Sun, X.; Ebert, M.-O.; Schweizer, W. B.; Purkayastha, N.; Beck, A. K.; Duschmalé, J.; Wennemers, H.; Mukaiyama, T.; Benohoud, M.; Hayashi, Y.; Reiher, M.; Helv. Chim. Acta 2013, 96, 799;
Haindl, M. H.; Schmid, M. B.; Zeitler, K.; Gschwind, R. M.; RSC Adv. 2012, 2, 5941.

73. Alemán, J.; Cabrera, S.; Chem. Soc. Rev. 2013, 42, 774; Sun, B. F.; Tetrahedron Lett. 2015, 56, 2133; Ishikawa, H.; Shiomi, S.; Org. Biomol. Chem. 2016, 14, 409; dos Santos, D. A.; Deobald, A. M.; Cornelio, V. E.; Ávila, R. M. D.; Cornea, R. C.; Bernasconi, G. C. R.; Paixão, M. W.; Vieira, P. C.; Corrêa, A. G.; Bioorg. Med. Chem. 2017, 25, 4620; Deobald, A. M.; Corrêa, A. G.; Rivera, D. G.; Paixão, M. W.; Org. Biomol. Chem. 2012, 10, 7681 .

74. Hong, B.-C.; Kotame, P.; Tsai, C.-W.; Liao, J.-H.; Org. Lett. 2010, 12, 776.

75. Melgar-Fernández, R.; González-Olvera, R.; Olivares-Romero, J. L.; González-López, V.; Romero-Ponce, L.; Ramírez-Zárate, M.; Demare, P.; Regla, I.; Juaristi, E.; Eur. J. Org. Chem. 2008, 655.

76. González-Olvera, R.; Demare, P.; Regla, I.; Juaristi, E.; Arkivoc 2008, VI, 61.

77. Ávila-Ortiz, C. G.; López-Ortiz, M.; Vega-Peñaloza, A.; Regla, I.; Juaristi, E.; Asymmetric Catal. 2015, 2, 37.

78. Bowmaker, G. A.; Chem. Commun. 2013, 49, 334; James, S. L.; Adams, C. J.; Bolm, C.; Braga, D.; Collier, P.; Friščić, T.; Grepioni, F.; Harris, K. D. M.; Hyett, G.; Jones, W.; Krebs, A.; Mack, J.; Maini, L.; Orpen, A. G.; Parkin, I. P.; Shearouse, W. C.; Steed, J. W.; Waddell, D. C.; Chem. Soc. Rev. 2012, 41, 413; Takacs, L.; Chem. Soc. Rev. 2013, 42, 7649.

79. Šepelák, V.; Düvel, A.; Wilkening, M.; Becker, K.-D.; Heitjans, P.; Chem. Soc. Rev. 2013, 42, 7507; Baláž, P.; Achimovičová, M.; Baláž, M.; Billik, P.; Cherkezova-Zheleva, Z.; Criado, J. M.; Delogu, F.; Dutková, E.; Gaffet, E.; Gotor, F. J.; Kumar, R.; Mitov, I.; Rojac, T.; Senna, M.; Streletskii, A.; WieczorekCiurowa, K.; Chem. Soc. Rev. 2013, 42, 7571.

80. Lazuen Garay, A.; Pichon, A.; James, S. L.; Chem. Soc. Rev. 2007, 36, 846.

81. Ralphs, K.; Hardacre, C.; James, S. L.; Chem. Soc. Rev. 2013, 42, 7701.

82. Friščić, T.; J. Mater. Chem. 2010, 20, 7599.

83. Braga, D.; Maini, L.; Grepioni, F.; Chem. Soc. Rev. 2013, 42, 7638; Friščić, T.; Jones, W.; Cryst. Growth Des. 2009, 9, 1621.

84. Duggirala, N. K.; Perry, M. L.; Almarsson, Ö.; Zaworotko, M. J.; Chem. Commun. 2016, 52, 640; Jones, W.; Eddlestone, M. D.; Faraday Discuss. 2014, 170, 9.

85. Wang, G.-W.; Chem. Soc. Rev. 2013, 42, 7668; Sarkar, A.; Santra, S.; Kundu, S. K.; Hajra, A.; Zyryanov, G. V.; Chupakhin, O. N.; Charushin, V. N.; Majee, A.; Green Chem. 2016, 18, 4475; Brahmachari, G.; RSC Adv. 2016, 6, 64676.

86. For a complete monograph about Mechanochemistry in organic synthesis, see: Margetic, D.; Štrukil, V.; Mechanochemical Organic Synthesis; Elsevier: Amsterdam, Netherlands, 2016.

87. Hernández, J. G.; Juaristi, E.; J. Org. Chem. 2010, 75, 7107; Štrukil, V.; Bartolec, B.; Portada, T.; Đilović, I.; Halasz, I.; 
Margetić, D.; Chem. Commun. 2012, 48, 12100; Landeros, J. M.; Juaristi, E.; Eur. J. Org. Chem. 2017, 687.

88. Konnert, L.; Gonnet, L.; Halasz, I.; Suppo, J.-S.; de Figueiredo, R. M.; Campagne, J.-M.; Lamaty, F.; Martinez, J.; Colacino, E.; J. Org. Chem. 2016, 81, 9802.

89. Ranu, B. C.; Chatterjee, T.; Mukherjee, N. In Ball Milling Towards Green Synthesis: Applications, Projects, Challenges, RSC Green Chemistry, No. 31; Ranu, B.; Stolle, A., eds.; The Royal Society of Chemistry: Cambridge, United Kingdom, 2015, ch. 1, p. 1.

90. Polindara-García, L. A.; Juaristi, E.; Eur. J. Org. Chem. 2016, 1095.

91. Hernández, J. G.; Friščić, T.; Tetrahedron Lett. 2015, 56, 4253.

92. Machuca, E.; Juaristi, E. In Ball Milling Towards Green Synthesis: Applications, Projects, Challenges, RSC Green Chemistry, No. 31; Ranu, B.; Stolle, A., eds.; The Royal Society of Chemistry: Cambridge, United Kingdom, 2015, ch. 4, p. 81.

93. Rodríguez, B.; Rantanen, T.; Bolm, C.; Angew. Chem., Int. Ed. 2006, 45, 6924; Rodríguez, B.; Bruckmann, A.; Bolm, C.; Chem. Eur. J. 2007, 13, 4710; Jörres, M.; Mersmann, S.; Raabe, G.; Bolm, C.; Green Chem. 2013, 15, 612.

94. Guillena, G.; Hita, M. C.; Nájera, C.; Viózquez, S. F.; Tetrahedron: Asymmetry 2007, 18, 2300; Guillena, G.; Hita, M. C.; Nájera, C.; Viózquez, S. F.; J. Org. Chem. 2008, 73, 5933. 95. Hernández, J. G.; Juaristi, E.; J. Org. Chem. 2011, 76, 1464.

96. Hernández, J. G.; García-López, V.; Juaristi, E.; Tetrahedron 2012, 68, 92.

97. Hernández, J. G.; Juaristi, E.; Tetrahedron 2011, 67, 6953.

98. Machuca, E.; Rojas, Y.; Juaristi, E.; Asian J. Org. Chem. 2015, 4,46 .

99. Machuca, E.; Granados, G.; Hinojosa, B.; Juaristi, E.; Tetrahedron Lett. 2015, 56, 6047.

100. Lisnyak, V. G.; Kucherenko, A. S.; Valeev, E. F.; Zlotin, S. G.; J. Org. Chem. 2015, 80, 9570.

101. Wan, W.; Gao, W.; Ma, G.; Ma, L.; Wang, F.; Wang, J.; Jiang, H.; Zhu, S.; Hao, J.; RSC Adv. 2014, 4, 26563.

102. Hu, X.-M.; Zhang, D.-X.; Zhang, S.-Y.; Wang, P.-A.; RSC Adv. 2015, 5, 39557.

103. Yadav, G. D.; Singh, S.; RSC Adv. 2016, 6, 100459.

104. Triandafillidi, I.; Bisticha, A.; Voutyritsa, E.; Galiatsatou, G.; Kokotos, C. G.; Tetrahedron 2015, 71, 932.

105. Pedotti, S.; Patti, A.; J. Sep. Sci. 2014, 37, 3451.

106. Gandhi, S.; Singh, V. K.; J. Org. Chem. 2008, 73, 9411.

107. Hernández, J. G.; Juaristi, E.; Chem. Commun. 2012, 48, 5396; Hernández, J. G.; Juaristi, E.; Educ. Chim. 2013,
24, 96; Hernández, J. G.; Ávila-Ortiz, C. G.; Juaristi, E. In Comprehensive Organic Synthesis II, vol. 9, $2^{\text {nd }}$ ed.; Knochel, P.; Molander, G. A., eds.; Elsevier: Amsterdam, Netherlands, 2014, p. 287.

108. Wells, M. J. M. In Chemical Analysis: Sample Preparation Techniques in Analytical Chemistry, vol. 162; Winefordner, J. D.; Mitra, S., eds.; John Wiley \& Sons, Inc.: Hoboken United States, 2003, ch. 2, p. 37.

109. Żwir-Ferenc, A.; Biziuk, M.; Pol. J. Environ. Stud. 2006, 15, 677.

110. Taygerly, J. P.; Miller, L. M.; Yee, A.; Peterson, E. A.; Green Chem. 2012, 14, 3020; Mack, J. In Ball Milling Towards Green Synthesis: Applications, Projects, Challenges, RSC Green Chemistry, No. 31; Ranu, B.; Stolle, A., eds.; The Royal Society of Chemistry: Cambridge, United Kingdom, 2015, ch. 8, p. 190.

111. Kokotos, C. G.; Limnios, D.; Triggidou, D.; Trifonidou, M.; Kokotos, G.; Org. Biomol. Chem. 2011, 9, 3386; Kaplaneris, N.; Koutoulogenis, G.; Raftopoulou, M.; Kokotos, C. G.; J. Org. Chem. 2015, 80, 5464.

112. Vega-Peñaloza, A.; Sánchez-Antonio, O.; Ávila-Ortiz, C. G.; Escudero-Casao, M.; Juaristi, E.; Asian J. Org. Chem. 2014, $3,487$.

113. Pearson, R. G.; J. Am. Chem. Soc. 1963, 85, 3533.

114. Attanasi, O. A.; Bartoccini, S.; Favi, G.; Giorgi, G.; Perrulli, F. R.; Santeusanio, S.; J. Org. Chem. 2012, 77, 1161.

115. Braun, M.; Angew. Chem., Int. Ed. 2012, 51, 2550.

116. Vargas-Caporali, J.; Juaristi, E.; Synthesis 2016, 48, 3890; Vargas-Caporali, J.; Cruz-Hernández, C.; Juaristi, E.; Heterocycles 2012, 86, 1275.

117. Olivares-Romero, J.; Juaristi, E.; Tetrahedron 2008, 64, 9992.

118. Reyes-Rangel, G.; Vargas-Caporali, J.; Juaristi, E.; Tetrahedron 2016, 72, 379.

119. Jung, M. E.; Piizzi, G.; Chem. Rev. 2005, 105, 1735.

120. Zhu, S.; Yu, S.; Ma, D.; Angew. Chem., Int. Ed. 2008, 47, 545; Mase, N.; Thayumanavan, R.; Tanaka, F.; Barbas III, C. F.; Org. Lett. 2004, 6, 2527.

121. Zhang, X.-J.; Liu, S.-P.; Lao, J.-H.; Du, G.-J.; Yan, M.; Chan, A. S. C.; Tetrahedron: Asymmetry 2009, 20, 1451.

122. He, T.; Gu, Q.; Wu, X.-Y.; Tetrahedron 2010, 66, 3195.

123. Bringmann, G.; Gulder, T. A. M.; Reichert, M.; Gulder, T.; Chirality 2008, 20, 628.

Submitted: September 21, 2017 Published online: November 27, 2017 